\title{
Konya Kentsel Alanının Büyümesinde Kentsel Saçaklanma ve Nedenleri
}

\section{Urban Sprawl and its Reasons in the Growth Process of Konya Urban Area}

D Hale Öncel, (1) Mehmet Çağlar Meşhur

Konya Teknik Üniversitesi Mimarlık ve Tasarım Fakültesi, Şehir ve Bölge Planlama Anabilim Dalı, Konya

\section{ÖZ}

Kentsel saçaklanma, 1950'lerden sonra dünyadaki pek çok kentte görülen bir büyüme biçimi olarak literatürde yer almaktadır. Kentlerin çevresine doğru düşük yoğunlukta, sıçramalı bir kentsel büyüme biçimi olarak tariflenen saçaklanma, kentsel alanın etkin kullanılmamasına ve çevresel sorunlara neden olmaktadır. Saçaklanmanın ortaya çıkmasında artan nüfus en önemli sebebi oluştursa da diğer etmenler de en az nüfus artışı kadar önem arz etmektedir. Genel olarak kabul gören sebepler, tüm dünyadaki kentlerin saçaklanma sürecindeki dinamikleri açıklamaya niyet etmektedir. Ancak ülkelerin kendi içlerinde siyasal, yasal, kültürel yapıları, gelişmişlik düzeyleri hatta kentleşme dinamikleri kentsel saçaklanma sürecinde farklı etkiler oluşturmaktadır. Dolayısıyla her ülke için saçaklanmanın ortaya çıkmasında etkili olan etmenlerin değerlendirilmesi, sürecin anlaşılması ve çözüm önerilerinin geliştirilebilmesi adına hayati öneme sahiptir. Bu çalışmanın amacı, kentsel saçaklanmayla ilgili literatürde yer alan genel etmenleri ele almakla birlikte Türkiye'de saçaklanmayı ortaya çıkaran dinamikleri ve Konya kenti özelinde saçaklanmaya neden olan etmenleri ortaya koymaktır. Konunun saha araştırması için kentsel saçaklanmanın belirgin biçimde yaşandığı Konya kenti seçilmiş ve uydu fotoğraflarından faydalanarak kentin makroformunun yıllar içerisindeki değişimi analiz edilmiş, ayrıca imar planları incelenerek planlama aracılığıyla kentin gelişimi üzerindeki etkileri de tespit edilmeye çalışılmıştır. Küresel anlamda tüm kentleri etkileyen etmenlerin yanında Türkiye'de 1980'lerden sonra dünya ekonomisine eklemlenme ve liberal politikalar nedeniyle kentlerde büyük değişimler meydana gelmiştir. Konya 1940'lardan itibaren planlı gelişen kentlerden biri olarak, konut ve planlama politikaları anlamında önemli kazanımlara sahip olmuştur. Son yıllarda ise kamu ve özel sermaye yatırımları kentin gelişiminde önemli bir rol oynamış ve Konya'ya özgü 'planlamanın kontrolünde' gerçekleşen saçaklanmayı ortaya çıkarmıştır. Anahtar sözcükler: Kentsel saçaklanma; kentsel saçaklanmanın nedenleri; Konya; Türkiye.

\begin{abstract}
Urban sprawl takes place in the literature as a form of growth seen in almost all cities in the world after 1950s. Urban sprawl, which is defined as a low density, leapfrog development towards the periphery of cities, causes ineffective use of urban space and environmental problems. Although increasing population is the most important reason of urban sprawl, other factors are as important as population growth. Generally accepted reasons intend to explain dynamics of sprawl. However, the political, legal, cultural structures, level of development and even urbanization dynamics of the countries have different effects on the urban sprawl process. Therefore, evaluating the factors causes of the sprawl for each country is vital for understanding the process and developing solutions. The aim of this study, in addition to addressing the factors in the literature related to urban sprawl, is to evaluate sprawling dynamics in Turkey and to reveal the factors that cause sprawling in the city of Konya. In the field research, the city of Konya was selected and the changes in the macroform of the city over the years were analyzed using satellite photographs. In addition, the effects of planning on the development of the city were tried to identify by examining city plans. Along with the factors affecting all cities globally, Turkey also has experienced major changes in cities due to its incorporation into the world economy after 1980s and liberal policies. Konya, as one of the cities that expands in a planned manner since the 1940s, has had important implementations in terms of housing/planning policies. In recent years, public and private capital investments have played important role and caused a type of sprawl specific to Konya which took place under the 'control of planning'.
\end{abstract}

Keywords: Urban sprawl; causes of urban sprawl; Konya; Turkey.

Bu çalışma, birinci yazar tarafından ikinci yazarın danışmanlığında üretilen 'Mekanın Tasarımı ve Kullanımına Bağıı Olarak Kentsel Yayılmayı Etkileyen Unsurlar: Konya Kenti

Örneği' (Selçuk Üniversitesi, Fen Bilimleri Enstitüsü, Şehir ve Bölge Planlama Anabilim Dalı- Yök tez no: 545246) isimli doktora tezinden faydalanarak hazırlanmıştır.

Geliş tarihi: 03.02.2020 Kabul tarihi: 03.01.2021

Online yayımlanma tarihi: I5.02.202I

İletişim: Hale Öncel

e-posta: sbpakseki@hotmail.com 


\section{Giriş}

Genel olarak kentleşmenin gelişimine bakıldığında Avrupa'da Sanayi Devrimiyle birlikte kentsel alanlara doğru göç hareketlerinin başladığı, ancak 20. yy’ın ortalarına kadar kentleşme hızının nispeten düşük ve büyük kentlerin sayısının oldukça az olduğu görülmektedir. Dünyada 1900'lerin başında nüfusu 500.000'i aşan 43 kent ve nüfusu I.000.000'u aşan 16 kent varken, 1950 yılından itibaren büyük kentlerin sayısı hızla artmıştır. Hali hazırda nüfusu I.000.000'u aşan kent sayısı 400'e yaklaşmıştır. Bu süreçte, kentler ve metropoliten alanlar çevrelerine doğru büyük bir hızla genişlemiştir/genişlemektedir. Bugüne kadar görülmüş en büyük (kentsel) yığılma, yayılmış metropoliten alanlarda deneyimlenmektedir ve bazı büyük kentsel bölgelerde nüfus on milyonlarla tarif edilmektedir (Berry, 2008). Kentlerin sayısı artmakla birlikte kentte yaşayan nüfus oranı da aynı hızla yükselmektedir. Dünya genelinde, 1900 yılında kentsel nüfus oranı \%9 iken, 1980'de \%40 ve 2000'de \%50'ye yükselmiştir (Mclntyre ve ark., 2008). Son tahminler ise 2050 yılında dünya nüfusunun \%70'inin kentlerde yaşayacağı yönündedir (OECD, 20I8). Burada dikkat edilmesi gereken bir başka konu, metropoliten alanlarda 1950-90 yılları arasında nüfus \%।28 oranında artarken yerleşik alanın \%।8I oranında artmış olmasıdır (Squires, 2002). Yine son tahminler, tüm dünyada 2000 yılında 603000 $\mathrm{km}^{2}$ olan toplam kentsel alanın 2050 yılında 3 milyon km²ye ulaşacağını göstermektedir (OECD, 20।8). Yirminci yüzyılın ikinci yarısından itibaren kentsel alanlarda nüfusun artmasının yanında hemen hemen tüm kentlerin çevrelerine doğru büyük bir hızla büyüdüğü görülmektedir. Kentlerin çevresine doğru, arada boşlukların bulunduğu (sıçramalı) ve düşük yoğunluklu bu yeni büyüme biçimi ‘kentsel saçaklanma' olarak adlandırılmakta$\operatorname{dır}$ (Karataş, 2007).

Genel çizgileriyle ifade edilen kentsel saçaklanma kavramının, teknolojik gelişmelerin tetiklediği, ağırlıklı olarak Amerikan kentlerine ilişkin bir olgu olduğu ve otomobilin yaygınlaşması ve bölgeleme gibi yaklaşımların etkisiyle ortaya çıktığı düşünülmektedir (Bruegmann, 2006). Kentsel saçaklanmayı ortaya çıkaran sebepler kabaca nüfus artışı, artan gelir ve ulaşımdaki gelişmeler olarak özetlense de dolaylı olarak farklı etmenler de saçaklanmayı arttırmaktadır. Bunların başında gelen küresel ekonomik büyüme ve dijital iletişim ağları, işgücünün desantralizasyonu yoluyla mekana bağımlılığı azaltarak, nüfusun ve işgücünün bir arada olma zorunluluğunu ortadan kaldırmaktadır. Elbette kent merkezinde arazi fiyatlarının yüksek olması gibi diğer ekonomik etmenler de yatırımcıları kent dışına iterek saçaklanmayı hızlandırmaktadır. Artan teknoloji ise başka bir etmendir. Konut teknolojisindeki gelişmeler, daha büyük ve yeni konuta olan talebi arttırmakta, ulaşım teknolojisindeki değişimler ise saçaklanmanın ana sebeplerinden biri olarak gösterilmektedir. 19. yy'da tren yolu ve tramvayın kentsel ulaşımda kullanılmasıyla ilk desantralizasyon başlamış ancak yürüme mesafesinin hala gözetildiği bir yerleşme biçimi oluşmuştur. 20. yy'da ise otomobil kentsel gelişmeyi biçimlendiren en önemli unsur olarak kentsel yoğunluğun düşmesinde etkili olmuştur. Bu yolla kentsel saçaklanma dolaylı olarak kentsel mekan ölçeğinde değişimlere sebep olmuş, erişilebilirlik gibi önemli alanlarda çözülmeleri hızlandırmıştır. Saçaklanma sonucunda kentsel fonksiyonlar birbirinden koparak mekanda ayrışmaya, ulaşımı motorlu araçla mümkün hale getirmeye başlamıştır. Teknolojik gelişmeler saçaklanma için çekici güçleri tanımlarken kent merkezindeki sosyal problemler ve olumsuz çevresel şartlar ise itici güçleri oluşturmaktadır. Tüm bu etmenler, kentlerin saçaklanmasında önemli bir yer tutsa da ülkelerin kendi iç dinamikleri, ekonomik yapıları, gelişmişlik düzeyleri, planlama pratikleri ve kültürel yapıları da saçaklanmanın biçimini belirlemektedir. Bu bağlamda, Türkiye 1980'lerden beri liberal ekonomik politikaların etkin olduğu gelişmekte olan bir ülke olarak küresel ekonomik sisteme eklemlenmeye çalışmaktadır. Bununla birlikte gelişmiş ülkelere kıyasla kırdan kente göç sürecini çok hızlı yaşamasından kaynaklanan kentsel sorunları da günümüzde çözmeye devam eden ve kentsel saçaklanmanın farklı biçimde ortaya çıktığı bir ülke olarak incelenmeye değerdir. Türkiye'de büyük kentlerde 1950'lerden sonra -yağ lekesi biçiminde, küçük alanların eklemlenmesiyle oluşan- kentsel yayılma tanımına uyan kentsel büyüme sürecinden sonra 1980'lerden itibaren kent çeperinde büyük alan kullanımlarının yaygınlaştığı, makroformdan kopuk ve çoğunlukla yoğunlukların düştüğü dolayısıyla kentsel saçaklanma tanımına uyan kentsel büyüme biçimi görülmeye başlanmıştır.

Bu çalışmanın ortaya çıkmasının arkasındaki soru, kentsel saçaklanma sürecinde küresel etmenlerin yanında ülkelerin içinde bulundukları koşullar ve planlama pratikleri/yaklaşımlarının da etkileri olup olmadığıdır. Bu çalışmanın amacı, kentlerin saçaklanmasında etkili olan küresel etmenlerle birlikte, Türkiye'de kentlerin saçaklanmasındaki dinamiklerin ortaya konması ve Türkiye'de kentsel saçaklanmanın yaşandığı kentlerden biri olan Konya kenti özelinde kentsel saçaklanmanın nedenlerini analiz etmektir. Bu bağlamda çalışmada, farklı ülkelerdeki kentlerde saçaklanmayı ortaya çıkaran unsurlara ve saçaklanmanın tarihine de kısaca değinilmiştir. Çalışmada, kentsel saçaklanmanın tanımı ve ortaya çıkaran nedenler derlendikten sonra Türkiye'de kentsel gelişme bağlamında saçaklanma tarihi ve nedenleri ortaya konmuştur. Tartışma kısmında ise Konya kentinde kentsel gelişme bağlamında saçaklanmanın ortaya çıkışı 2 ölçüt (yoğunluk ve sıçramalı gelişme) kullanılarak değerlendirilmiş ve literatürden saptanan etmenler çerçevesinde saçaklanmanın nedenleri tartışılmıştır. Yöntem olarak, Konya'daki nüfus yoğunluğu ile ilgili yapılan tez ile makalelerden ve Büyükşehir Belediyesi arşivindeki uydu fotoğraflarından ve nüfus yoğunluğu haritalarından faydalanılmıştır. Etmenleri saptayabilmek için ise, Büyükşehir Belediyesi web sitesinden faydalanarak son 20 yılda hayata geçen yatırımlar tespit edilmiş ve Google Earth uygulamasından bu yatırımların yerleri belirlenmiştir. Son olarak, yapılan çalışmanın bulgularının değerlendirilmesi, sonuçlarının paylaşımı yer almaktadır. Elde edilen 
bulgular, Türkiye'deki pek çok kentte olduğu gibi 1960'lardan sonra Konya kentinde de kentsel nüfusun hızla artmasına rağmen planlama deneyimi güçlü bir kent olarak Konya'da gecekondu gibi yasadışı konut alanları oluşmadığını göstermektedir. 1980'lerden sonra yeni ekonomik paradigmalar sonucu kentlerde yaşanan kamusal yatırımların desantralizasyonu sürecinin Konya kentinde de yer bulduğu görülmektedir. Bu dönemde planlar aracılığıyla da kentsel alan düşük yoğunlukla ve sıçramalı bir gelişme deseniyle çepere doğru hızla genişlemiştir. Sonuç olarak, Konya kentinde ülkenin planlama anlayışının çok uzağına düşmeyen ancak planlama eliyle kentsel saçaklanmanın ortaya çıktığı bir kentsel büyüme süreci yaşanmıştır.

\section{Kentsel Saçaklanmanın Kısa Tarihi, Tanımı ve Nedenleri}

Kentsel saçaklanmanın tarihi kentlerin tarihi kadar geriye gitmektedir. Antik kentlerde saçaklanma olgusu görülmekte hatta nüfusu I milyon olan antik Roma kentinde 'suburbium' denilen ve surların dışında kalan alanlar bulunmaktadır. Ancak kentsel saçaklanmanın sorun olarak kabul edilmesi Sanayi Devriminin kentler üzerindeki etkileriyle birlikte başlamıştır. Bu dönemde kentlerde aşırı nüfus yığılması, konut ve çalışma alanlarının ayrılması fikrini doğurmuş, dolayısıyla belli bir düzeyde saçaklanmanın ortaya çıkmasına sebep olmuştur (Yaşar, 2010). Fishmann (2002), 19. yy'ın ilk yarısında, büyük Avrupa kentlerinin tarihsel duvarlarını yıkarak kırsal alana doğru ihtiyatsız bir hızla genişlediklerini belirtmektedir. Londra, I8. yy'ın sonunda I,I milyon nüfusa ulaşmış, bu büyüme nüfus yoğunluğunun artmasına neden olmuştur. Endüstri devriminin sonuçlarını en yoğun yaşayan ulus olarak İngilizler, 19. yy'ın ortalarında orta sınıf olarak adlandırılan ve yoğun-karmaşık kent merkezinde yaşayan bir sosyal sınıfın doğuşuna tanıklık etmiştir. Kent merkezinin sorunları, imkanı artan orta sınıf ve burjuva sınıfını kent dışına itmeye başlamıştır. 18. yy'da hafta sonu villaları olarak başlayan desantralizasyon süreci daha sonra uydu kentlerin inşasıyla devam etmiştir. Benzer süreçleri yaşayan Paris'de ise uydu kent yerine apartmanlaşmayla sorunların çözülmesi yoluna gidilmiştir (Couch ve diğ., 2009). $\mathrm{Bu}$ dönemde ortaya çıkan ütopist yaklaşımlarda da benzer biçimde kentsel fonksiyonların kırsal alana doğru kaydığı görülmektedir. Robert Owen, kent ütopyasını oluştururken işçilerin, olumsuz çalışma ve yaşam koşullarından etkilenmiştir. Modelinde kırsal alanda kentin olumsuz etkilerinden uzak, ancak kentin sağladığı faydaları içeren uyumlu bir düzen kurmaya çalışmış ve endüstri toplumunu kır topluluklarına taşımıştır (Akkoyunlu Ertan, 2004). Ebenezer Howard'ın Bahçekent modelinin de asıl amacı, işçilerin yaşam kalitesini yükseltmektir. Bunu, kent ve kır yaşamının sağlıklı, doğal ve ekonomik bir birleşimini oluşturarak yapmaya çalışmıştır. Modelin dayandığı ana fikir merkezde kamusal kullanımları konumlandırarak, konut alanı ve sanayi alanlarını çepere taşımakla birlikte yeni yerleşim alanlarına ihtiyaç duyulduğu takdirde kentin büyümesini sınırlandırarak, yeni kentlerin inşa edilmesini önermek- tedir. Bu haliyle konut ve sanayi alanlarını desantralize etse de, bir yandan kentin büyüklüğünü kontrol altında tutmayı da amaçlamaktadır (Howard, 1902). Amerika'da ise Frank Lloyd Wright Broadacre modelinde, kent ve kır ayrımını ortadan kaldıracak bir model önermiş, daha da ileriye giderek insanların kırsal alanı kaplayan çiftliklerde yaşaması gerektiğini savunmuştur (Wright, 1932). Bu dönemde hem Amerika hem İngiltere'de düşük yoğunluklu konut alanları arzu edilen ve haklı bulunan bir modele dönüşmüştür (Couch ve diğ., 2009). Modernizm hareketinin öncülerinden Le Corbusier'in Çağdaş Kent ütopyasında ise kent merkezinde gökdelenler yer alırken yerleşimin \%95'i açık alanlardan oluşmaktadır. Kenti sınırlayan ve yeşil alanlardan oluşan bir koruma bandı da öneren Corbusier, bandın dışında bahçeşehirlerin yer alacağını öngörmüştür (Corbusier, 1987). Bu haliyle kentin büyümesini kontrol altında tutmaya çalışan bir yaklaşıma sahip olduğu söylenebilir. Diğer yaklaşımlardan farklı olarak, Le Corbusier modern teknolojiden faydalanarak kentsel yoğunlukları arttırma yoluna gitmiştir. Yüksek katlı binaların arasında kalan açıklıklar ise açık alan ve kamusal alan olarak değerlendirilmiştir (Couch ve diğ., 2009). Özetle Sanayi Devrimi sonrası ortaya çıkan ütopist kent yaklaşımlarında kentsel fonksiyonlar desantralize edilmekle birlikte, kenti sınırlama yönünde bir çabanın da varlığı söz konusudur ve daha sonraki dönemde bu fikirler kentlerin biçimlenişinde önemli etkiler doğurmuştur.

Günümüzde kentsel saçaklanma olarak tanımlanan olgu, 2. Dünya Savaşından önce, otomobile bağımlılı̆̆ın artması ve yol ağının genişlemesiyle birlikte nüfusun kentlerden banliyölere doğru kaymasıyla dramatik biçimde kentleşmenin hız kazanması durumudur. Bu süreçte, otoyolların yaygınlaşması ve kent çeperindeki arazi vergilerinin düşük olması konut alanlarıyla birlikte iş yerlerinin de kent dışına kaymasına sebep olmuştur. Hatta geçtiğimiz yıllarda sadece banliyölerin değil, kenar şehir (edge city) olarak adlandırılan kentten kopuk ve bağlantısı olmayan kentsel alanların da yaygınlaştığı görülmektedir (Barnes ve ark., 200I).

Kentsel yayılma ve saçaklanma, son yıllarda kentsel büyümenin en belirgin biçimi olarak literatürde yer almaktadır. Kentsel büyümeden farklı bir anlam ifade eden kentsel saçaklanma (urban sprawl) terimi ile genel anlamda kentlerin olması gerekenden fazla, düşük yoğunlukla ve arada boşluklar bırakarak genişlemesi anlaşılmaktadır. Her ne kadar kentler artan nüfus için genişlemek zorunda olsa da saçaklanma ile kastedilen bu alanın nüfusun ihtiyacının çok üzerinde olmasıdır (Brueckner, 2000). Kentsel saçaklanma üzerine yapılan ilk tanımlar, kentsel form ölçütleri ve sonuçlarıyla birlikte ele alınmıştır. Genel olarak düşük yoğunluklu, sıçramalı, merkezi olmayan, tek işlevli arazi kullanımına sahip, otomobil bağımlı, planlanmamış, bant biçiminde, zayıf erişilebilirlik ve fonksiyonel açık alanların olmadığı yerleşme biçimi olarak tanımlanmıştır (Galster ve diğ., 200I, Ludlow, 2006, Harvey ve Clark, 197I, Pendall, 1999 Weitz ve Moore, 1998, Frumkin ve ark.,2004, Squires, 2002, Barnes ve ark., 200I, Ewing ve ark., 2002). 
Erişilebilirlik göstergesinin ortaya çıkmasında saçaklanmanın temel karakteristiği olan düşük yoğunluklu gelişmenin payı büyüktür. Toplu taşımayı verimsiz kılan en önemli etmen düşük yoğunluklu gelişme desenidir (Frumkin ve ark., 2004). Düşük yoğunluk ve tek işlevli arazi kullanımı bir araya geldiğinde kaçınılmaz olarak ortaya zayıf erişilebilirlik çıkmaktadır. Banliyölerin ilk oluşumu sırasında plancılarının başarmaya çalıştıkları model, konutların açık alanların içerisinde ve daha kırsal karakterde olduğu düşük yoğunluklu konut alanlarıdır. Burada gözden kaçan nokta, açık ve yeşil alanların neredeyse tamamının özel mülkiyete ait olmasıdır. Dolayısıyla kamusal açık alanlar düşük yoğunluklu bölgelerde neredeyse hiç bulunmamaktadır (Gillham, 2002).

Kentsel saçaklanmanın tanımına yönelik son yıllarda ortaya çıkan genel bir fikir birliğinden söz edilecek olursa, öncelikle çok boyutlu bir olgu olmasıyla birlikte tipik olarak plansız, düzensiz, farklı nedenlerden dolayı ortaya çıkan ve kentsel alanı etkin olmayan bir şekilde kullanan büyüme biçimi olarak tariflenebilir. Kentsel saçaklanma tüm dünyada görülmesine rağmen karakteristikleri ve etkileri çeşitlenmektedir (Oueslati ve diğ., 20I5). Kentsel saçaklanma, ortalama nüfus yoğunluğunun çok yüksek olduğu kentlerde bile görülebilen bir büyüme biçimidir. Eğer kentsel alan, büyük miktarda düşük yoğunluklu alan içeriyorsa saçaklanmadan söz edilebilir. Bu durum, desantralize olmuş, saçaklanmış, nüfusun büyük kısmının kent merkeziyle ilişkisiz alanlarda yaşadığı kentlerde ortaya çıkmaktadır. Kentsel saçaklanma ile ilgili pek çok tanım bulunmakla birlikte genel bir problemden söz etmek mümkündür. Olguyu tanımlarken sebep ve sonuçlarının karışıklığa neden olmasıdır. Bu durum öznel değerlendirmelerin ortaya çıkmasına sebep olmaktadır. Örneğin otomobil bağımlılığı, kentsel saçaklanmanın sonucu iken genellikle tanımının içerisinde yer almaktadır. Bu noktada kentsel saçaklanmanın sebep ve etkilerinden ayrıştırılmış, esas karakteristiklerini ortaya koyan bir tanımlamaya ihtiyaç duyulmaktadır. Saçaklanmanın sonuçları olan zayıf erişilebilirlik, otomobil bağımlılığı ve çevresel zararlar gibi etkiler dışarıda bırakıldığında saçaklanmanın yapısı ile ilgili bir tanıma ulaşılmaktadır. Bu çalışmada kabul edilen ve son çalışmalarda ortaya konduğu üzere kentsel saçaklanma; düşük nüfus yoğunluğu ile karakterize edilen, desantralize olmuş ve sıçramalı gelişmenin görüldüğü bir kentsel büyüme biçimidir (OECD, 20I8).

Kentsel saçaklanma ile birbirine anlam yönünden yakın olan kentsel yayılma teriminin literatürde birbiri yerine kullanıldığı görülse de, kentsel yayılma (urban expansion) kentlerin yağ lekesi biçiminde çevrelerine doğru genişlemesi olarak tariflenmektedir. Kentsel yayılma daha çok gelişmekte olan ülkelerin kentlerinde görülmektedir. Kentsel yayılma, sıçramalı gelişme yerine arada boşluk bırakmayan ve aynı yoğunlukla gelişmeyi sürdüren bir büyüme biçimidir (Wei ve Ewing, 2018). Bunun yanında, kentsel yayılma farklı biçimlerde de görülebilmektedir. Mevcut kentsel alanda aynı yoğunlukta, artan veya azalan bir yoğunlukla olabildiği gibi kentsel alandaki boşlukların dolmasıyla veya kent çeperindeki boş alanların yapılaşmaya açılmasıyla (kentsel alana bitişik ya da sıçramalı) gerçekleşebilir. Kentsel yayılmanın ortaya çıkma biçiminde 6 etmen etkilidir. Bunlar; doğal çevre, demografik yapı, ekonomik yapı, ulaşım sistemi, tüketici talepleri ve yönetim olarak sıralanabilir (Angel ve diğ., 2005). Kentsel saçaklanma, kentsel yayılmanın bir türü olan sıçramalı yayılmayı ifade etmektedir. Başka bir deyimle saçaklanma yalnızca anakentin büyüyerek dışa doğru genişlemesini değil, aynı zamanda etki bölgesindeki ve yakınındaki yeni yerleşmelerin ortaya çıkması veya var olanların gelişerek kent fizyonomisine bürünmesi ve bu anakente eklemlenmesini ifade etmektedir (Kaygalak, 2006).

Kentsel saçaklanmanın tanımı ile ilgili fikir birliğine varılsa da, ülkelerin kendi dinamikleri saçaklanmanın derecesini değiştirmektedir. Amerikan banliyölerine özgü (geniş parselller, büyük konutlar, gelişmiş otoyol ağı vb.) kentsel saçaklanma, Avrupa ve diğer dünya ülkelerinde benzer niteliklerde görülmeyebilmektedir. Amerikan kentlerindeki saçaklanmış banliyöler, Avrupa kentlerindeki banliyölerden her zaman daha büyük olmuş ve daha hızlı gelişmiştir. Ayrıca Amerika'da banliyö ve kent merkezindeki konut alanlarının yaşam koşulları arasında daha derin farklılıklar bulunmaktadır. Kentsel saçaklanmanın, kentin çeperine doğru düşük yoğunluklu ve otomobil bağımlı bir yerleşme deseni olarak tanımlanmasına Amerikan banliyölerindeki bahçeli ve geniş konutlar sebep olmuştur. Banliyö biçiminde kentsel gelişme Amerikan kentlerinin tipik yerleşme deseni olarak kentlerin büyük alanlara yayılmasının temel nedenlerinden biridir. Amerika'ya özgü bir takım olgular da Amerikan kentlerinin saçaklanmasının arkasındaki nedenleri oluşturmaktadır. Bunlar; Amerika'da kent merkezindeki konut fiyatlarının çok yüksek olması, ulaşım maliyetlerinin ise oldukça düşük olması, araba sahipliliği oranının diğer ülkelere kıyasla çok erken başlamasıdır. Şöyle ki; Amerika'da 1960 yılında çalışanların \%64'ü işe arabayla giderken, bu oran 1970'de \%78'e, 1980'de \%84'e yükselmiştir. Almanya ise ancak 1970 yılında, Amerika'nın 1920 yılındaki araba sahipliliğine erişebilmiştir. Bunların yanında, 1950-1980 arası hane halkı gelirlerinin yükselmesinin yanında mortgage faizlerinin düşmesi, kent merkezine kamu yatırımı sınırlıyken, ulaşım altyapısına yatırımların artması, Avrupa'ya kıyasla oldukça fazla göç almasıyla birlikte heterojen nüfus yapısının olması Amerika'da banliyölerin hızla artmasının sebeplerindendir (Nechyba ve Walsh, 2004). Heterojen nüfus yapısı, orta-sınıf beyaz Amerikalıların kendilerini siyahilerden ve çok etnikli kent merkezinden ayırmalarının nedeni olmuştur. Böylece 1950'de \%40 olan kent merkezi dışında yaşayan nüfus oranı, 1990'da \%60'a yükselmiştir (Couch, 2009). Yapılan çalışmalar, Amerika'da etnik azınlık nüfus oranının fazla olduğu ve kent merkezindeki suç oranlarının yüksek olduğu yerleşmelerde kentsel saçaklanmanın hızlandığını ortaya koymuştur (Oueslati ve diğ., 20I5). Tüm bu etmenlerin yanında trafik, gürültü ve suçtan uzakta yeterli açık ve yeşil alana sahip konutlara ulaşma fikri de saçaklanma- 
yı arttırmıştır (Cobbinah ve Amoako, 20I2). Yaklaşık 100 yıl önce şehir plancısı Patrick Geddes bir tahminde bulunmuş ve Amerika'nın kuzeydoğu sahilindeki kentleşmenin ileride kıyı bandı boyunca 50 mile ulaşacağını söylemiştir. $O$ dönemde gerçek dışı olarak nitelendirilen bu tahmin günümüzde gerçeğe dönüşmüştür (Gillham, 2002). American Farmland Trust tarafından 2002 yılında yapılan analizler, 1982 ve 1997 yılları arasında Amerika nüfusunun \% 17 oranında artarken kentsel alanın \%47 oranında arttığını ortaya koymuştur. Başka bir araştırmaya göre, 1950-1990 yılları arasında metropoliten alanın yoğunluğunda büyük değişimler yaşanmıştır. Metropoliten alanlar 84 milyon kişiyi 208.000 mil$^{2}$ de barındırırken, 1990'da 193 milyon kişiyi 585.000 mil$^{2}$ de barındırmaktadır. Diğer deyişle nüfus yoğunluğu mil' 'ye 407 kişiden 330 kişiye düşmüştür. Benzer biçimde 1950 yılında nüfusun \%57'si ve işgücünün \%70'i kent merkezinde bulunurken bu oran 1990'da \%35 ve \%45'e düşmüştür (Squires, 2002; Powell, 2007).

Avrupa ise güçlü planlama sistemi sayesinde kentsel saçaklanmayı kontrol altında tutmayı nispeten başarabilmiştir. Yine de tüm Avrupa kentlerini bir arada değerlendirmek doğru olmayacağı gibi, Avrupa ülkelerinin kendi içindeki farklı koşulları kentlerin büyüme biçimini etkilemiştir (Couch ve diğ., 2009). Kıta içindeki kentsel saçaklanma varyasyonları büyük coğrafi çeşitliliği, arazi kullanım politikalarını, ekonomik koşulları ve kültürel yapıyı yansıtmaktadır (Oeslati ve diğ, 20I5). Avrupa'da kentler, modern ulaşım sistemlerinin kentsel alanları biçimlendirmesinden önce kurulduğu için geleneksel olarak daha kompakt ve yoğun bir tarihi çekirdeğe sahiptir. Avrupa kentlerinin sahip olduğu avantajlardan biri de güçlü yerel yönetimlere sahip olmalarıdır (Couch ve diğ., 2009). Üstüne üstlük, Amerika'nın aksine Batı Avrupa'da toplu taşımaya önemli oranda kamu kaynakları aktarılmakta, kent merkezinin imkanlarını iyileştirmeye yönelik büyük çaba harcanmaktadır (Nechyba ve Walsh, 2004). Buna rağmen Avrupa'da da benzer bir süreç yaşanmış ve tüm göstergeler savaş sonrası dönemden itibaren kentsel alanların nüfus artışından daha hızlı büyüdüğünü ortaya koymuştur. Ve bu eğilimde hiçbir yavaşlama görülmemektedir. Tüm Avrupa kentlerinde, tarihi kentler kompakt bir merkeze sahip olsa bile son yıllarda kentler çevresine doğru hızla genişlemektedir. 1950'lerden beri Avrupa kentleri \%78 oranında genişlerken, nüfusu artışı \%33 düzeyinde kalmıştır. Bitişik, apartman ve yoğun bölgelerin yerini bağımsız konut birimleri almaktadır. Oldukça somut bir örnek olarak, Palermo'da (İtalya) nüfus artışı \%50 iken yapılaşmış alan \%200 oranında artmıştır (Ludlow, 2006).

Batı Avrupa ülkeleri, 2. Dünya Savaşının ertesindeki yeniden inşa sürecinden sonra uzun bir ekonomik büyüme periyoduna girmiştir. Bu büyüme hızlı kentleşmeyi beraberinde getirmiş, I 2 yıl içerisinde kentsel alanlar Belçika'da \% I5, Danimarka ve Fransa'da \%23 oranında genişlemiştir. Bazı kentsel alanlar büyümeye devam ederken, Kuzey-Batı Avrupa'daki kent bölgeler yüzyılın ortasında ekonomik büyüme anlamın- da zirveye ulaşmış ve sonrasında merkezdeki istihdam olanakları merkezden uzaklaşmaya başlamıştır. Güney Avrupa'da ise çoğu kent bölge, yüzyılın sonuna kadar büyümeye devam etmiştir. Doğu Avrupa ülkeleri ise merkezi planlamanın güçlü olması sayesinde savaş sonrası dönemde kentsel saçaklanmayı kontrol altına almayı başarmıştır. Örneğin Varşova'da, ancak 1978'den sonra banliyö nüfus artış hızı kent merkezinden fazla olmuştur (Couch ve diğ., 2009). Hatta sosyalist ülkelerde 1985'den önce banliyöleşme süreci, kentsel büyüme üzerinde kapitalist ülkeler kadar etkili olamamıştır. Dolayısıyla, sosyalist ülkelerde kentler daha kompakt bir formda gelişmiş, 1990'lara kadar da birbirleriyle büyük benzerlikler göstermiştir. Dramatik değişim 1989'da kominizmin çökmesiyle başlamış, sosyalist yapı politik, ekonomik ve kurumsal açıdan değişim geçirerek demokratik ve serbest piyasa ekonomisini temel alan bir yapıya evrilmiştir. Böylece Orta ve Doğu Avrupa kentlerinde yapısal değişimlerle birlikte Batılı değerler yer edinmeye başlamış, alışveriş merkezleri, yeni konut tipleri, golf sahaları, tematik parklar gibi Amerikan değerleri ve yaşam biçiminden etkilenen işlevlerle kentler küresel süreçlerle entegre olan bir yapıya kavuşmuştur. Kent merkezinde yer talebi artan ofis ve ticari birimler, merkezdeki arsa fiyatlarını yükseltmiş ve çeperdeki fiyatla arasındaki farkın açılmasına sebep olmuştur. Çeperdeki değişimler ilk olarak Prag'da başlayıp sonra Orta ve Doğu Avrupa kentlerinde de görülmeye başlanmıştır (Milanovic, Korycka ve Rink, 2009).

Gelişmekte olan ülkelerde ise, kentler daha hızlı büyümekle birlikte yayılım alanı, nüfus miktarı gibi niceliksel karakterleriyle gelişmiş ülkelerdeki kentleşme sürecinden farklılık göstermektedir. Birleşmiş Milletlerin yaptığı nüfus projeksiyonlarında Türkiye gibi gelişmekte olan ülkelerin kentli nüfusunun giderek yükselen bir artış oranı göstereceği öngörülmektedir. 1980'lerden sonra bu ülkelerde hızlı bir mega kentleşme sürecinin başladığı ve gelişmiş ülkeleri geride bırakan bir niceliğe ulaştığı görülmektedir. Gelişmekte olan ülkelerin kentleşmesini belirleyen bir başka değişim ise, dünyada geleneksel sanayiye dayalı üretimin çözülmesi ile emek yoğun sanayinin gelişmiş ülkelerden gelişmekte olan ülkelere kaymasıyla yaşanmıştır. Küreselleşmeyle birlikte sermaye ve yatırımların global hareket serbestliği, gelişmiş ülkelerde sanayisizleşme (deindustrialization) sürecine yol açarken, 1990'larda küresel ekonomik piyasaya hızlı bir şekilde eklemlenmeye çalışan ülkelerde kentleşme formunu belirlemiştir. Bu ülkelere aktarılan geleneksel ağır ve kirli sanayinin gerektirdiği işgücünün, kırsaldaki yapısal dönüşümle birleşmesi, bu dönemde hızı bir kentleşme sürecini başlatmıştır. Türkiye'de de olduğu gibi bu değişim sadece kırlardan kentlere değil, kentlerden kentlere göçle sonuçlanarak büyük kentlerin daha da büyümesine neden olmuştur (Kangalak ve Işık, 2007).

Her ülkenin ve kentin koşulları saçaklanmanın biçimi ve derecesi üzerinde önemli etkiler doğurmaktadır. Her yerleşmenin kendi bağlamında ele alınması doğru olmakla birlikte, yine de literatürde kentsel saçaklanmayı ortaya çıkaran, kü- 
resel anlamda kabul görmüş genel nedenlere değinmek tüm kentler için geçerli olan etmenleri anlamak açısından önemlidir. Ekonomistler üç ana faktörün saçaklanmayı tetiklediğini düşünmektedir. Bunlar, nüfus artışı, artan gelir ve ulaşım olanaklarının gelişmesidir (Brueckner, 2000). Yapılan çalışmalar ve araştırmalar çerçevesinde, kentsel saçaklanmanın ana sebepleri 7 başıı altında ifade edilebilir (Gillham, 2002; Ludlow, 2006). Bunlar, makro ekonomik etkenler, mikro ekonomik etkenler, demografik etkenler, konut tercihleri, kentsel sorunlar, ulaşım ve planlamadır (Tablo I).

\section{Makro Ekonomik Etkenler}

Küresel ekonomik büyüme, kentsel saçaklanmayı tetikleyen en önemli unsurlardan biridir. Ekonominin küreselleşmesi günümüzde bilgi ve iletişim teknolojilerinin gelişimiyle ilişkilidir. Her iki olgu da hem nüfusun hem de işgücünün mekanda dağılması sonucunu ortaya çıkarmaktadır (Ludlow, 2006). Ekonominin küreselleşmesi giderek artmakta, üretim faaliyetini desantralize ederek, kontrol ve yönetim mekanizmalarını merkezileştirmektedir. Daha önce bahsedildiği gibi bu eğilim özellikle gelişmekte olan ülkelerde kentsel saçaklanmayı giderek hızlandırmaktadır (Squires, 2002). Diğer yandan küreselleşme de, sınırları ortadan kaldırarak kentlerin entegrasyonunu kolaylaştırmaktadır. Böylece büyük kentler veya metropoller daha hızlı büyüme eğilimi göstermektedir. Ayrıca küresel rekabet perakende ticaretin de biçimini değiştirmiştir. 1950'lerde ticarethaneler daha küçük, konut alanlarının içerisinde ve yürüme mesafesinde iken günümüzde perakende ticaretin en baskın biçimi kent dışında veya içinde kurulan alışveriş merkezleri tarafından karşılanmaktadır. Alışveriş merkezleri etrafındaki geniş otoparklarıyla büyük alanları kaplamakta ve sadece otomobille ulaşımı mümkün kılmaktadır. Ulaşım ağlarının hızlı biçimde gelişmesi en fazla kent çekirdeğinin dışındaki alanları etkilemektedir ve bu ağlar eski yollara kıyasla daha fazla yer kaplamaktadır (Ludlow, 2006).

Bir diğer önemli etken, elektronik iletişimin dünyayı çok hızlı biçimde dönüştürmesidir. Dijital iletişim ağları, elektrik hatlarının, telgraf ve telefonun daha önceki dönemlerde yaptığından daha köklü biçimde kent formunu değiştirmektedir. Özellikle telefon pek çok işyerinin bir arada bulunma zorunluluğunu ortadan kaldırmıştır. Telefonun yaygınlaşmasını takip eden süreçte, yaklaşık 50 yıl sonra bilgisayarların ağa bağlanmasıyla birlikte bu etki katlanarak çoğalmıştır. Son dönemlerde internetin yaygınlaşmasıyla şirketlerin büyük kısmı ofıs dışı çalışma oranlarını arttırmaktadır. Bu ilişkinin en tipik örneklerinden biri, 200I yılında ABD'de federal ajansların işgücünün \%25'ini ofis dışı alanlardan sağlamasıdır (Gillham, 2002).

\section{Mikro Ekonomik Etkenler}

Kentsel saçaklanmayı tetikleyen unsurlardan bir diğeri de kent merkezindeki yüksek arazi fiyatlarıdır. Bu durum insanları ve
Tablo I. Kentsel yayılmanın sebepleri

\section{Kentsel yayılmanın başlıca sebepleri}

Makro- Ekonomik Etkenler

Ekonomik gelişme

Küreselleşme

İletişim Teknolojileri

Konut Tercihleri

Kişi başına düşen alan miktarının artmas

Konut tercihlerinin değişmesi

Kentsel Sorunlar

Hava kirliliği

Gürültü

Küçük yaşama/konut birimleri

Güvenlik problemi

Sosyal problemler

Açık-yeşil alanların yetersizliği

Mikro- Ekonomik Etkenler

Yükselen yaşam standardı

Arazi fiyatları

Tarım alanlarının ucuzlaması

Özel mülkiyet

Demografik Etkenler

Nüfus artışı

Konut üretimindeki artış

Planlama

Düzenleme ve standartlar

Bölgeleme (zoning) yaklaşımı

Zayıf arazi kullanım planı

Planların uygulanma sürecindeki zorluklar

Yatay ve dikey koordinasyondaki ve işbirliğindeki problemler

yatırımcıları arazi fiyatlarının kıyasla daha düşük olduğu kent çeperine doğru itmektedir (Powell, 2007). Ayrıca sermayeyi kendine çekmeye çalışan kentler de gelişmenin önündeki sınırları esnetmektedir. Dolayısıyla kent çevresindeki tarım alanları veya doğal peyzajlar ticari veya endüstri yatırımları için uygun hale getirilmektedir (Ludlow, 2006).

Burada vurgulanması gereken bir diğer nokta, günümüzde serbest pazar ekonomisine geçiş yapan ülkelerde özel mülkiyetin önem kazanmasıdır. Kentsel arazinin büyük oranda özel mülkiyete ait olması kentsel toprağın alınıp satılabilen bir meta gibi algılanmasına ve kullanılmasına sebep olmaktadır. Piyasa koşullarında toprak, alım-satım değeri ile ölçülen ve parsellere bölünüp parçalanabilen bir yapıya sahiptir. Diğer yandan emlak piyasası da yapılaşmayı tetiklemektedir, çünkü üzerinde yapı olan bir arazinin değeri yükselmektedir (Gillham, 2002). Tüm 
bu nedenler, arsa spekülasyonuna ve tarımsal gelirin, toprağın kentsel kullanıma dönüşümü sonucunda elde edilecek gelire karşı düşük olmasına sebep olmaktadır (Karataş, 2007). Dolayısıyla mikro ekonomik etkenler de kentsel saçaklanma için zemin hazırlamaktadır.

\section{Sosyal Etkenler}

Daha önce belirtildiği üzere kentsel saçaklanmayı sadece nüfus artışı değil farklı demografik etkenler de tetiklemektedir. İnsanların pek çoğu eski konutları terk etmekte ve yeni bir evde veya bahçeli evde oturmayı istemektedir. Dolayısıyla üst ve orta gelir grubu, seçme imkanları arttığında, kent merkezinden uzaklaşabilmektedir (Ludlow, 2006; Soule, 2006). Konut teknolojisi ve toplu konut sektöründeki gelişmeler son yıllarda kentleri etkileyen önemli unsurlardan bir diğeri haline gelmiştir. Konutun oldukça hızlı biçimde üretilebilmesi, yeni tasarımlar vb. etmenler büyük ve yeni konuta olan talebi arttırmaktadır (Karataş, 2007). Bu anlamda, son yıllarda konut ve yakın çevresi için eskiye kıyasla çok daha fazla miktarda alan tüketilmektedir.

\section{Konut Tercihleri}

Mimarlık ürünleri, toplumun ya da dönemin sosyal, kültürel, toplumsal, ekonomik ve siyasal karakteristik özelliklerini yansıtan ve bu dönemlere tanıklık eden varoluşlar olarak tanımlanır. Dolayısıyla günümüz toplumlarında tüketim alışkanlıkları, sanal olarak üretilen ihtiyaçlar doğrultusunda şekillenmekte ve konut da bir toplumsal statü aracına dönüşmektedir. Konut artık bir barınma aracı, mahremiyet ve aidiyet duygularının yaşandığı bir mekandan ziyade bir rant aracı olarak görülmektedir (Atakan, 2018). Son yıllarda insanların konut satın alma kararlarını etkileyen faktörler müteahhit firmanın güvenilirliği, konutun güvenlikli site içerisinde olması ve bahçe, oyun ve park alanlarının site içerisinde olması şeklinde belirtilmektedir. Ekonomik durumları daha yüksek olan kişiler ise villa tipi konutları tercih etme eğilimindedir. Gelir arttıkça talep edilen konutun büyüklüğü artmaktadır (Abar ve Karaaslan, 2013, Kaba, 2008). Dolayısıyla daha büyük yaşam alanına olan talep kentsel saçaklanmanın önemli nedenlerinden biri olarak gösterilmektedir. Bunların yanında ulaşım olanaklarındaki gelişmeler, kentlerde ulaşımı daha hızlı ve daha konforlu hale getirmekte, böylece özellikle banliyöler daha çekici hale gelmektedir (Brueckner, 2000).

İnsanların son yıllarda kent merkezinde çalışı, banliyöde yaşamak yönünde talepleri artmaya başlamıştır. Daha geniş konutlara oluşan talep, yerel yönetimleri kent merkezinde insanları çalışıp eğlenebilecekleri alanlar oluşturmaya itmektedir. $\mathrm{Bu}$ durumun kente tezahürü kent merkezinde yüksek katlı iş merkezleri, kongre merkezleri, spor alanları ve kültürel alanlar olarak yansımaktadır. Kent merkezindeki yoğunluk da insanların yaşamak için tercihlerinin kent dışına doğru kaymasına sebep olmaktadır (Powell, 2007).

\section{Kentsel Sorunlar}

Kentsel saçaklanma olgusunu ortaya çıkaran etmenlerden bir bölümü de kent merkezindeki fiziksel ve sosyal dönüşümlerden kaynaklanmaktadır. Kent merkezindeki sosyal problemler, güvenlik sorunları, olumsuz çevresel şartlar saçaklanmayı hızlandıran güçlü etmenlerden birkaçıdır. Kent merkezi pek çok kişi için gürültülü, güvensiz ve kirli yerler olarak tariflenmektedir. Açık ve yeşil alanların az miktarda olması, özellikle çocuklu ailelerin kent içerisinde yaşamayı tercih etmemelerine sebep olmaktadır. Kent merkezinde yer alan konutların merkez fonksiyonlarına dönüşmesiyle birlikte üst gelir grubu konut alanlarını çeperlere taşımaktadır. Diğer yandan kent merkezinde arsa arzının sınırlı ve fiyatının çok yüksek olması da bu süreci tetiklemektedir (Soule, 2006).

\section{Ulaşım}

20. yy’da otomobilin günlük hayatta kullanılmaya başlaması, kentsel gelişmeyi biçimlendiren en önemli unsurlardan biri olmuştur. Otomobil, kentsel saçaklanmayı her yöne mümkün hale getirmiş, düşük yoğunluklu konut alanlarının doğuşuna ve kentsel fonksiyonların birbirinden ayrılmasına (desantralizasyon) sebep olmuştur. Otomobilin icadından beri kişisel otomobil sahipliliğinde tüm dünyada sürekli artan bir durum söz konusudur. Artan otomobil sahipliliği kentsel saçaklanmanın sınır tanımamasına neden olmaktadır (Arbury, 2005). Yanı sıra, planlamada da otomobil odaklı ulaşım sistemi benimsenmekte ve bu durum kentlerin kontrolsüz biçimde saçaklanmasını tetiklemektedir. Çoğu bölgede toplu ulaşımın zayıf olması ulaşım alternatiflerini daraltarak tek seçeneğin otomobil olduğu bir sistem oluşturmaktadır (Gillham, 2002). Ulaşım altyapısının ilerlediği noktaya kadar yerleşme gelişme eğilimi göstermekte ve bu durum kısır bir döngüye dönüşmektedir.

\section{Planlama}

20. yy'ın ikinci yarısından sonra ortaya çıkan bölgeleme anlayışı kentsel alanlar üzerinde önemli etkiler ortaya çıkarmıştır. $O$ dönemde fabrikaları, ticarethaneleri, dolayısıyla insanları dağıtma/ yayma yolunda bir süreç başlamışır (Frumkin ve ark., 2004). Planlama sürecinde tek fonksiyon için bölgeleme yapılması saçaklanmayı tetikleyen bir faktördür (Bruegmann, 2006). Bunun yanında planlama sürecinde sınırlandırıı ve etkin planlama-bölgeleme politikalarının oluşturulamaması saçaklanmayı oluşturan sebepler arasında sayılmaktadır (Karataş, 2007).

Kentsel saçaklanmayı ortaya çıkaran diğer bir faktör de planlamayı etkileyen düzenleme ve standartlardır. Saçaklanmanın ciddi biçimde görüldüğü kentlerde özellikle birbirinden bölgeleme yoluyla ayrılmış kentsel fonksiyonlar öne çıkmaktadır. Tüm fonksiyonları bölgeleme yaparak birbirinden ayırmak, daha sonra standartlara uygun taban alanı ve çekme mesafeleri vererek yapıları hem yollardan hem de diğer 
yapılardan ayırmak ortaya kentsel toprağın etkin bir şekilde kullanılmadığı bir yapılaşma çıkarmaktadır. Elbette tüm standartlar kamu sağı̆̆ını korumak için oluşturulmuştur. Ancak saçaklanmanın görüldüğü kentlerde fonksiyonların birbirinden ayrılması aşırı biçimde ortaya çıkmaktadır. Özellikle eski kentsel alanlarla kıyaslandığında aradaki fark açık biçimde görülmektedir (Gillham, 2002).

Planlama sürecindeki problemler saçaklanmanın daha derin yaşanmasına sebep olmaktadır. Çünkü her ne kadar ulaşım biçimindeki değişimler, zayıf toplu ulaşım, arazi fiyatlarındaki değişimler temel sebeplerden sayılsa da, asıl problemin tüm değişkenleri iyi yönetecek planlama sürecinin yoksunluğundan kaynaklandığı söylenebilir.

\section{Türkiye'de Kentsel Gelişmenin Tarihi ve Kentsel Saçaklanma}

Dünya'da kentsel saçaklanmaya neden olan küresel sebeplerin tümü, Türkiye'de kentsel saçaklanmanın ortaya çıkmasında açıklayıcı olmakla birlikte Türkiye'ye özgü farklı yapılar, politikalar da kentlerin büyümesinde etkili olmaktadır. Türkiye'de 2. Dünya Savaşı sonrasında hızlı bir kentleşme yaşanmıştır. 1923'de Ankara'nın başkent olarak ilan edilmesiyle ve Cumhuriyet'in yeni, modern, çağdaş bir kent kurma idealiyle birlikte 1930 yılı Cumhuriyet'in kentleşme ideolojisinin ve standartlarının belirlenmesi bakımından önemli yılları oluşturmaktadır. 1950'lere kadar süren radikal modernite dönemi, çok partili siyasete geçilmesiyle birlikte yerini popülist bir moderniteye bırakmıştır. 1946'da çok partili seçimlerle birlikte yasal kararları, oy kaygılarının ve popülist kaygıların belirlediği bir döneme geçilmiştir. Bu dönemde kapital birikim hızının düşük olması ise yerel yönetimlerin gelirlerinin kısıtlı olmasına ve gelirlerini arttıracak esnekliğe de sahip olmamalarına da neden olmaktadır. Aynı zamanda kırsal alanda başlayan çözülme kentlere göç hareketini arttırmış, Türkiye'nin kapital birikiminin yeni iş alanları yaratacak, altyapı ve konut yapacak yeterlilikte olmaması da kentleşme sorunlarını ortaya çıkarmıştır (Tekeli, 20।3). Türkiye'de kentleşmenin hız kazanması Avrupa'daki süreçlerden farklı bir seyir izlemiştir. Bunun en temel sebebi Sanayi Devrimi ve sonrasında Batı'da yaşanan hızlı kentleşmenin, Türkiye'de 1950'lerde göç hareketleriyle başlamış olmasıdır. Öte yandan Batı'nın sanayiye dayalı kentleşmesi ile gelişmekte olan ülkelerin kentleşmesinin aynı nitelikte bir süreç oldukları görüşüne katılmak olanaklı değildir. Batı'da sanayiin verimi tarımsal işgücünü, büyük kentlerde sanayide çalışmak üzere harekete geçirmiş, dolayısıyla ekonomik gelişmeyle birlikte nüfusun çoğunluğu hizmetlerde toplanmıştır. Kentleşme, nüfusun tarımdan kentsel kesimlere kaymasına koşut olduğundan, gelişmiş ülkelerin kentleşmeleri, haklı olarak kalkınma ile özdeş sayılmıştır. Gelişmekte olan ülkelerde ise kentleşme sanayileşmeden önce gitmekte, kesim değiştiren faal nüfus, tarımdan doğruca hizmet dallarına aktarılmaktadır. $\mathrm{Bu}$ ülkelerin kentlerinde gelir dağılımı da daha adaletsiz bir duruma gelmektedir (Keleş, 1996;30). Bu süreçte Türkiye'deki büyük kentlerin pek çoğunda konut açığı nedeniyle gecekondu olgusu ortaya çıkmıştır. Gecekondular genelde kentin çeperindeki kamu arazilerinde kendine yer bulmuş ve daha sonra imar aflarıyla yasallaşmıştır. Günümüzde dönüşüm geçiren gecekondu alanları büyük kentlerin genişlemesinde önemli etmenlerden biri olarak karşımıza çıkmaktadır (Yaşar, 2010). Çoğunlukla kent çeperinde düzensiz, yasalara aykırı olarak gelişen ve kentsel yapılaşma sorunu olarak görülen gecekondu yapıları ve mahalleleri zaman içerisinde artarak kentsel dinamikleri etkilemeye başlamıştır. İlk başlarda yerel idarelerin yıkımlarına karşı tutunma çabası gösteren gecekondular, belli bir sayıya ulaşıp yerel idareleri seçmede etkin politik güce erişince mevcut yapılarıyla ilgili mülkiyet hakkı ve yapılaşma hakkı talebiyle gündeme gelmiştir (Tercan, 2018;20).

1950'lerden 1980'lere kadar hakim olan kent biçimi, ekonomik gerekçelerin doğurduğu mekanizmalarla oluşmuştur. Dönemin kapital birikim koşulları ve imar anlayışı konut sorununun çözümünde yetersiz kalmıştır ve konut sunum biçimi olarak yap-satçı girişim ortaya çıkmıştır. Böylece tek tek parselin üzerine binaların eklenmesiyle büyüyen kentler, yağ lekesi gibi çevresine doğru yayılmıştır. Bu durum, güçsüz kapitalin dönüştürdüğü kentler olarak tariflenebilir (Tekeli, 20I3). Türkiye kentleşme politikası, kentsel nüfusun genel nüfustan daha hızlı artmakta olduğu gerçeğine koşut olarak şekillenmiştir. 1985'lere kadar 'Bölgelerarası denge' ilkesinden uzaklaşmadan kentleşmenin desteklenmesi benimsenirken 1985'den sonra büyük kentlerdeki yığılmanın önlenmesi esas alınmıştır. Hatta 1996'dan sonra nüfusu I milyonu aşan kentlere doğru olan göç eğilimin yavaşlatılmasına, orta büyüklükteki kentlerin geliştirilmesine yönelik politikalar benimsenmiştir (Keleş; 1996; 54-59).

1980 sonrasında ise Türkiye'nin dişa açılması ve ekonomik paradigmasının değişmesine paralel olarak sermaye piyasaları oluşmuştur. Bu gelişmeler sonucunda, büyük projeler için büyük miktarda sermayeyi bir araya getirebilme kapasitesi elde edilmiştir. Bu dönemde yeni bir konut sunum biçimi olarak toplu konut ortaya çıkmıştır. Toplu konutla birlikte toplu ulaşım projeleri (metro vb.) kentlerin oluşma dinamiği ve formlarını değiştirmeye başlamış, bu dönemde organize sanayi bölgeleri, serbest bölgeler, üniversite kampüsleri, hastane kampüsleri ve toplu konutlar yapılmıştır. Artık kentler yağ lekesi gibi tek tek binaların eklemlenmesiyle değil büyük parçaların eklemlenmesiyle büyümeye başlamıştır. Otoyolların da gelişmesiyle kentin büyük parçalar halinde çepere sıçraması gerçekleşmeye başlamıştır (Tekeli, 20I3). Türkiye'nin yaşadığı neo-liberal dönüşüm politikaları ile inşaat sektörü gerek ekonomik gerek siyasi amaçlara ulaşmanın aracı olarak kullanılmıştır. İnşaat sektörünün ilk büyüme dönemi 1982-88 arası, ikinci büyüme dönemi ise 2002-2008 arasında yaşanmıştır. Yanı sıra, 1985'de yürürlüğe giren İmar Kanunu ile planlama yetkileri büyük oranda yerel yönetimlere devredilmiştir. 
Sonrasında kentlerde imar ve yapım faaliyetleri ciddi biçimde artmış ve kentlerin çeperinde yer alan kentsel araziler hızlı ve kolay bir biçimde kentsel arsaya dönüştürülüp, inşaat faaliyetlerine konu olmuştur (Balaban, 20I I). Aynı dönemde kamu yatırımlarının desantralizasyonu da devreye girerek kentlerin çeperinde spekülasyona ve kentsel alanın normal seyrinden daha hızlı genişlemesine sebep olmuştur (Yaşar, 2010). İnşaat sektörünün ikinci büyüme evresi olan 2002 yılı sonrasında ise benzer süreçler yaşanmış ve devlet inşaat sektöründeki büyümeyi teşvik edecek (TOKI gibi) yapılanmaya gitmiştir. Bu dönemde devlet müdahaleleri arasında inşaat yatırımları için arsa ve arazi tahsisi de yer almaktadır (Balaban, 20 I I). Türkiye'deki büyük kentlerde 1980'lere kadar yağ lekesi biçiminde tarif edilen kentsel yayılma süreci yaşanmışken, 1980'lerden itibaren kent çeperinde büyük arazilerin yapılaşmaya konu olduğu kentsel saçaklanma olarak nitelendirilebilecek bir kentsel büyüme süreci yaşanmaktadır.

\section{Yöntem}

Bu çalışmada kentsel saçaklanma ile ilgili etmenlerin ve göstergelerin Konya kentsel alanında değerlendirilmesi amaçlanmaktadır. Bunun için makroformun yıllar içerisindeki değişimi analiz edilmiştir.

Kentsel saçaklanmanın ölçülmesinde iki boyut önem kazanmaktadır. İlki kentsel alanda nüfus yoğunluğunun nasıl dağıldığı ve kentsel alanın nasıl parçalandığıdır. Bu boyutlar farklı ölçütlerle ölçülmektedir. En yaygın kullanılan ölçüt, kentsel alanda nüfus yoğunluğunun değişimidir. Nüfus yoğunluğu ile ilgili bir diğer ölçüt, nüfus yoğunluğunun belirli eşiklerin altında olduğu alanlarda yaşayan nüfus dağılımı (I500, 2500 ve $\left.3500 \mathrm{kişi/} / \mathrm{km}^{2}\right)$ ve bu eşiklerin altında nüfus yoğunluğuna sahip alan oranıdır. Saçılmayla ilgili ise, kentsel alanın saçılma derecesi, yüksek yoğunluklu alanların sayısı (çok merkezlilik) ve yüksek yoğunluklu alanların dışında yaşayan nüfus oranıdır (desantralizasyon) (OECD, 20I8). Bu çalışmada kentsel alanda nüfus yoğunluğunun değişimi ve kentsel alanın saçılma durumu ölçütleri Konya kentsel alanı için ele alınmıştır.

Kentsel saçaklanmanın temel göstergeleri olan düşük yoğunluk ve sıçramalı gelişmenin saptanabilmesi için Konya'daki nüfus yoğunluğu ile ilgili yapılan tez ile makalelerden ve Büyükşehir Belediyesi arşivindeki uydu fotoğraflarından faydalanarak tespitler yapılmış ve Konya Büyükşehir Belediyesi Kent Bilgi Sisteminde yer alan nüfus yoğunluğu haritalarından faydalanılmıştır. Uydu fotoğraflarının kullanılmasının sebebi imar planlarında yerleşmeye açılan alanların öngörüldüğü gibi yapılaşmaya açılmaması diğer deyişle piyasa koşullarında yatırımcıların uygun araziyi seçmeleri sonucu arada boşlukların olduğu bir yapılaşmanın ortaya çıkmasıdır. Bu durumda imar planlarından ziyade uydu fotoğrafları gerçeği daha sağlıklı yansıtmaktadır. Ayrıca Belediyeden elde edilen imar planları incelenmiş ve yıllar içerisinde yeni kentsel gelişme alanlarını tespit edebilmek için planlar üst üste çakıştırılarak zaman içerisinde planlama aracılığıyla ortaya çıkan kentsel alan değişimi saptanmıştır. Bunun yanında Konya Tarım ve Hayvancılık Genel Müdürlügüunden toprak kabiliyeti etüdlerinden verimli tarım toprak grupları verileri elde edilmiştir.

Konya kentinde saçaklanmayı ortaya çıkaran etmenleri saptayabilmek için kentteki özel ve kamu yatırımları yer seçimleri incelenmiştir. Büyükşehir Belediyesi web sitesinden faydalanarak kentte saçaklanmanın ciddi anlamda arttığı 2000 yılından itibaren hayata geçen yatırımlar tespit edilmiş ve Google Earth uygulamasından bu yatırımların yerleri belirlenmiştir. Diğer yandan Ocak 2015-Ağustos 2016 zaman aralığında kentte 3 farklı dönemde yapılaşmış (1950 öncesi, 1950-2000 arası, 2000 sonrası) 10.24I konut analiz edilmiştir. Bunun için Büyükşehir Belediyesinden elde edilen halihazır haritalar üzerinde arazi kullanımı güncellendikten sonra AutoCAD programı kullanılarak konut büyüklükleri hesaplanmıştır. Böylece literatürde ortaya konan etmenlerle Konya kentindeki saçaklanmanın ilişkisi saptanmaya çalışılmıştır.

\section{Konya Kentinde Kentsel Gelişme Bağlamında Saçaklanmanın Ortaya Çıkışı}

Konya kenti 1940'lı yılların ortalarından itibaren kent planına sahip olan ve planlı gelişen bir yerleşme özelliğiyle Türk kent planlama tarihi açısından önemli bir değere sahiptir. Konya kentine yönelik hazırlanan ilk kapsamlı ve bütüncül kent planı 1946 yılında hazırlanmıştır (Kömürcüoğlu, 1946) (Şekil I).

Konya kentinde kırdan kente göç hareketlerinin başladığı 1960'lardan sonra nüfus artışılla birlikte kentsel büyümenin hız kazandığı görülmektedir. Bu dönemde, hızlı nüfus artışının ortaya çıkardığı fiziksel baskı ve talepler, 1965 yılında yeni bir kent planının yapılması gereğini doğurmuştur (Taşçı ve Berksan, 1967) (Şekil 2).

1980'li yıllara kadar ülkedeki imar faaliyetlerini yönlendiren temel unsur, hızlı nüfus artışının ve denetimsiz kentleşmenin yarattığı toplumsal ve mekânsal sorunların çözümlenmesi olmuştur. Bu bağlamda Konya kentinde 1965-1980 yılları arasında yasadışı konut üretimini önleme ve nitelikli konut sağlama amacıyla gecekondu önleme bölgeleri planlaması yapılmıştır. Bu sürecin gelişiminde 1966 yılında yürürlüğe giren ve yasadışı konut bölgeleri ile mücadeleyi amaçlayan 775 sayılı Gecekondu Yasası'nın etkili olduğu söylenebilir. İlk planlama eylemi 1967 yılında I Numaralı Gecekondu Önleme Bölgesi (Aydınlıkevler Mahallesi), ikincisi 1970 yılında 2 Numaralı Gecekondu Önleme Bölgesi (Nalçacı Caddesi) ile başlamış ve o dönemin konut üretim biçimi olan kooperatif girişimciliği ile süreç tamamlanmıştır. 1980 yılında ilave imar planı üretilen 4 Numaralı Gecekondu Önleme Bölgesi ise kentin kuzey gelişme koridoru üzerinde yer alan Cumhuriyet ve Binkonut Mahalleleridir. Türkiye'de büyük kentlerde yaşanan gecekondu olgusu Konya kentinde doğru konut ve planlama politikaları neticesinde or- 


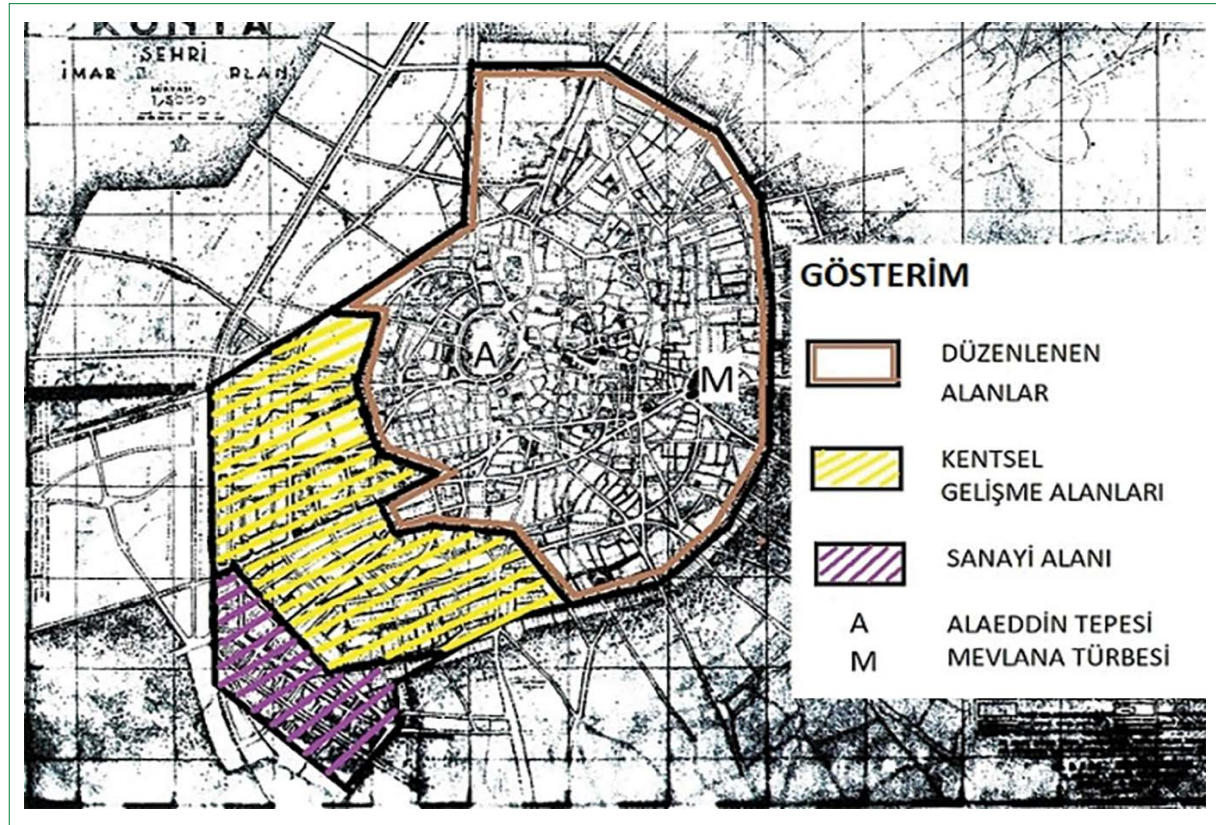

Şekil I. 1946 Konya İmar Planı- kentsel arazi kullanım şeması (Baydar, 1954 ve Yenice, 20I2'den faydalanarak hazırlanmıştır).

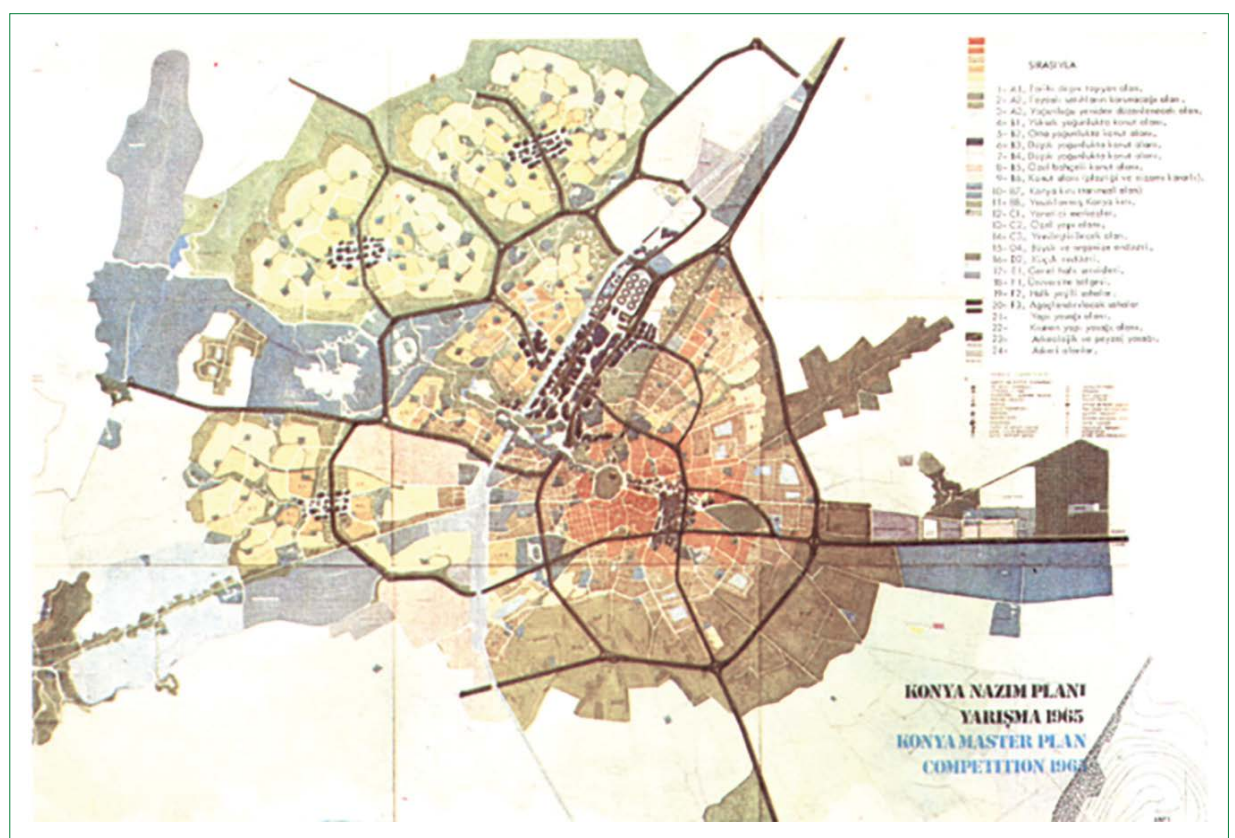

Şekil 2. 1965 Konya İmar Planı- kentsel arazi kullanım şeması, (Kaynak: Taşçı ve Berksan, 1967).

taya çıkmamıştır. Bu dönemde gerçekleştirilen imar faaliyetleri temelde küçük etaplar biçiminde ele alınarak kente eklemlenen yeni alanlar şeklinde gerçekleştirilmiştir. 1965 imar planının ardından başlayan ve 1980'li yıllara kadar devam eden süreçte Konya kentinin mekânsal gelişimi, ilave ve mevzi imar planları ile yönlendirilmiştir. 1984'de onaylanan Konya Çevre Düzeni Planı ise kenti kuzey yönde geliştirme ilkesini sürdürmüştür. Üniversite alanı, sanayi alanı ve konut alanları için kuzeyde yer seçimi yapılmıştır (Yenice, 20I2). Bu yer seçim kararları konut alanlarının kuzeye doğru büyük bir hızla fakat arada boşluklar bırakarak gelişmesine neden olmuştur (Şekil 3).

1999 yılında ilk büyük kent planı niteliğindeki I/25.000 ölçekli Nazım İmar Planı hazırlanmıştır. Bu plan, kentin metropoliten düzeydeki yerleşme büyüklüğünün yeni konut alanlarının gelişiminin yanı sıra kentin çeperindeki köy ve kasabaların eklenmesi ile sağlanacağını öngörmektedir. Üç ana koridor (kuzey-kuzeybatı, kuzeydoğu ve güney koridoru) kentin ge- 


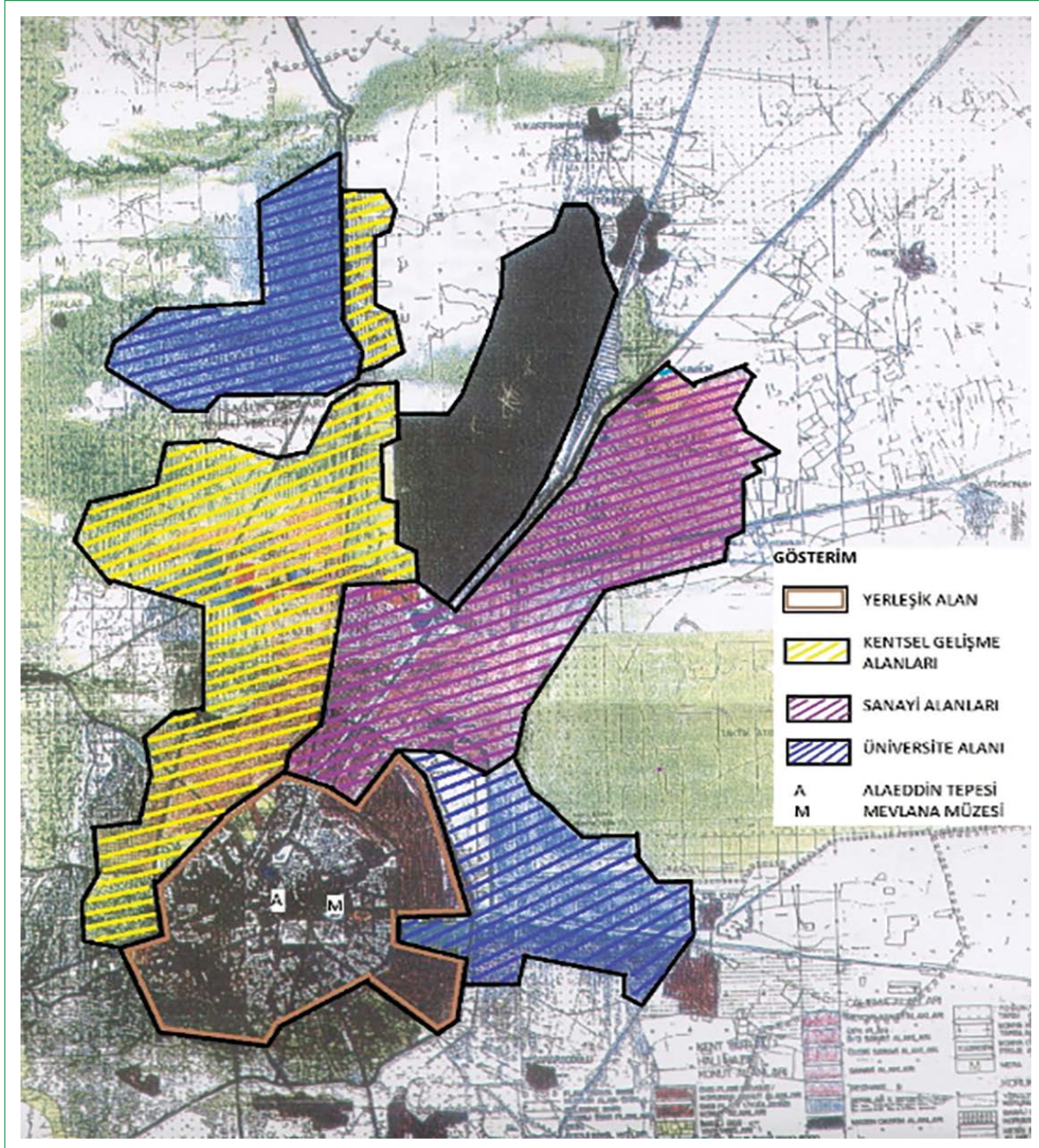

Şekil 3. 984 Konya Çevre Düzeni Planı- kentsel arazi kullanım şeması (Taş̧, I 983’den faydalanarak hazırlanmışır).

lişme yönleri için alt bölgeleri oluşturmaktadır (Yenice, 20I0). Bu haliyle plan, kentsel saçaklanmanın temel göstergelerinin (bant biçiminde gelişme, sıçramalı gelişme) planlama aracılı̆̆ıyla oluşturulduğu bir plan şeması niteliği taşımaktadır.

Kentsel saçaklanma, ülkelerin ve kentlerin dinamiklerine göre farklı nitelikler göstermektedir. Türkiye kentlerinde, Amerika'daki gibi banliyöleşme sürecinde yaşanan nitelikte bir kentsel saçaklanma yaşanmamış ancak nüfus yoğunluğunun azalması, kentten kopuk sıçramalı gelişme ve bant şeklinde gelişme gibi saçaklanmanın temel karakteristiklerinin ortaya çıktığı kentsel büyüme biçimleri yaygınlaşmıştır. Genel olarak kentsel saçaklanmanın temel göstergeleri açısından değerlendirildiğinde Konya kenti ciddi anlamda saçaklanma ile ilişkili karakteristikleri yansıtmaktadır. Bunlardan en önemlisi nüfus yoğunluğunun azalmasıdır. 1980'lerden sonra kentsel yoğunlukların azalması durumu Konya kentinde belirgin biçimde yaşanmış hatta 1999'a kadar kentsel alan artışı kentsel nüfus artışının 16 katına çıkmışıı (Akseki, 20II). Türkiye'de Bü- yükşehir Belediyesi statüsündeki kentler arasında Van kentsel alanı (5I kişi/ha ile) en düşük, Konya kentsel alanı ise 63 kişi/ ha ile ikinci en düşük nüfus yoğunluğuna sahip yerleşmedir (Sılaydın Aydın ve Kahraman, 2019). Tablo 2 ve Şekil 4'ten de izlendiği üzere 1980 'lerden sonra kentte nüfus yoğunluğu sürekli azalmaktadır.

Konya Büyükşehir Belediyesinin 2020 yılına ait nüfus yoğunlukları analizi göstermektedir ki kent merkezinde yüksek nüfus yoğunluğuna (200-700 kişi/ha) sahip konut alanları yer alırken çeperlerde nüfus yoğunluğu azalmaktadır (Şekil 5). Saçaklanmanın en önemli göstergelerinden olan kentten kopuk sıçramalı gelişme alanları ise yapılan analizde açıç̧a görülmektedir. 2000 'lerden sonra kentte yapılaşmaya başlayan kuzeydeki gelişme alanına ilişkin fotoğraf ve görüntülerden izlenebileceği üzere fonksiyonların birbirinden ayrıldığı ve arada boş-kullanılmayan alanların bulunduğu sıçramalı gelişme görülmektedir. Saçaklanmanın temel göstergelerinden olan bant biçiminde gelişme de ana arterler boyunca ortaya çıkmaktadır (Şekil 6-8). 
Tablo 2. Konya'da imar planlarıyla oluşturulan kentsel alan verileri

\begin{tabular}{lcccc}
\hline Arazi kullanım biçimi & 1946 planı & 1966 planı & I983 planı & I999 planı \\
\hline Yerleşme büyüklüğü (ha) & 816 & 2.378 & 12.850 & 29.052 \\
Plan öneri konut alanları (ha) & 534 & 1.867 & 8.506 & 16.610 \\
Plan projeksiyon nüfusu & 75.000 & 350.000 & 1.300 .000 & 1.800 .000 \\
Gerçekleşen nüfus & 150.000 & 550.000 & 700.000 & 1.346 .000 \\
Yoğunluk (kişi/ha) & 140 & 190 & 153 & 105 \\
\hline
\end{tabular}

Kaynak: Yenice, 2005.

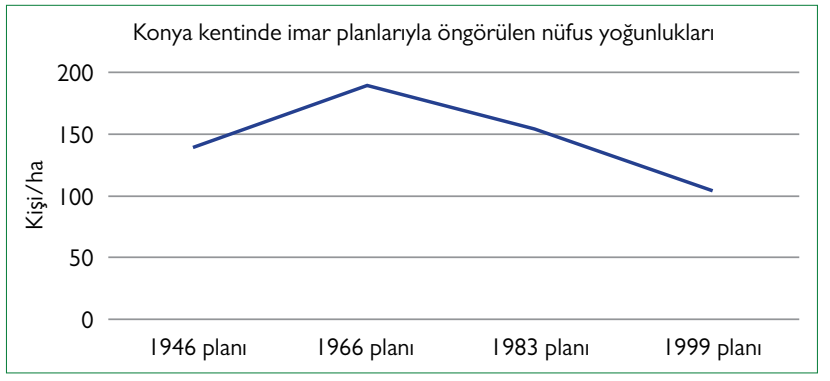

Şekil 4. Nüfus yoğunluğu değişimi.

Konya gibi tamamı verimli tarım toprakları üzerine kurulmuş bir kent için saçaklanma, hem ekonomik hem çevresel anlamda büyük kayıpları beraberinde getirmektedir. 1950, 1973, 2003 ve 2013 yıllarına ait uydu fotoğrafları ile Tarım ve Köy İşleri Müdürlüğünün hazırladığı verimli tarım toprakları analizi çakıştıııldığında, yıllar içerisinde yapılaşmaya açılan tarım alanları görülebilmektedir (Şekil 9).

Literatürde yer alan ve kentsel saçaklanmanın ortaya çıkmasında etkili olan tüm nedenler Konya'nın yayılma sürecinde önemli bir yer tutmaktadır. Daha önceki bölümde ele alındığı üzere etmenler, Konya özelinde alt başlıklar altında değerlendirilmiştir.

\section{Makro ve Mikro Ekonomik Etmenler}

Son yıllarda makro ekonomik etkenler Konya kentinin gelişiminde ve yer seçim kararlarında etkisini göstermektedir. Özellikle küresel rekabetin yeni perakende ticaret biçimi olan AVM'lerin kentte ulaşım ağlarıyla ilişkili ancak büyük kısmının arazinin ucuz olduğu kent çeperinde yer seçtiği görülmektedir (Şekil 10). Bunun yanında Konya kentinin saçaklanma sürecinde genel olarak mikro ekonomik etkenlerin de büyük paya sahip olduğu görülmektedir. Yıllar içerisinde kent merkezindeki yüksek arazi fiyatları yatırımcıları kent çeperine itmiştir. Şekil 10'da görüldüğü üzere son yıllarda neredeyse tüm kamu ve özel sektör yatırımları kentin makroformunun dışında ya da çeperinde yer seçmiştir. Dolayısıyla Türkiye'deki pek çok kentte görülen kamu yatırımlarının desantralizasyonu Konya kentinde de yaşanmış ve üniversite kampüsü ve otogar gibi önemli kamu yatırımları kentin kuzeye doğru hızla genişlemesine sebep olmuştur. 1982 yılında Selçuk Üniversitesi kampüs alanı inşaatıyla birlikte kentin kuzeyinde önem- li bir yatırım başlamış ve kent merkezinden yaklaşık $20 \mathrm{~km}$ uzaklıkta bir çekim merkezi oluşmaya başlamıştır. Bu durum kampüs alanının doğusunda üniversite öğrencilerinin hem sosyal hem de fiziksel anlamda kentten kopuk yaşam alanı olan bir mahallenin (Bosna Hersek mah.) oluşmasına neden olmuştur. Şehirlerarası otobüs terminali ise 2000 yılında hizmete başlamış ve günümüzde kent içerisinde kalsa da, yine o dönemde kentten kopuk bir kamu yatırımı olarak yer almıştır. Benzer biçimde 2007 yilında Beyhekim Devlet Hastanesine de kentsel alanla bağlantısı olmayan bir yer seçimi yapılmıştır. Kentsel alan kuzeye doğru gelişmesine rağmen günümüzde Hastane hala kent makroformunun dışında kalmakla nadir görülen bir yer seçim kararına konu olmaktadır. Bunların yanında 2007 yılında Adliye, 2010 yılında Karatay Üniversitesi, 2017 yllında Necmettin Erbakan Üniversitesi kampüsü ve kentsel rekreasyon alanları da dahil olmak üzere kamu yatırımlarının neredeyse tamamının kentsel alanın dışında yer seçmesi kentin saçaklanması üzerinde ciddi etkilere sahiptir. Son yıllarda arazi maliyetinin düşük olduğu alanlarda konut projelerinin yanında TOKi, hastane, özel okul, otel gibi özel sektör veya kamu yatırımlarının da yer seçtiği görülmektedir. Tüm yer seçim kararlarından sonra konut alanlarının da kent çeperine doğru hızla genişlediği görülmektedir.

\section{Sosyal Etkenler ve Konut Tercihleri}

Konya özelinde sosyal etkenler de saçaklanmanın ortaya çıkmasında önemli bir faktörü oluşturmaktadır. Kent merkezindeki sosyal problemler ve güvenlik sorunlarının yanında son yıllarda Suriyeli göçmenlerin ucuz konuta ulaşabilmek ve yüksek erişilebilirliğe sahip olabilmek adına kent merkezini tercih etmesi, orta ve üst gelir grubunun konut taleplerini merkezin dışına kaydırmışıı. Diğer yandan tüm dünyada görülen daha büyük yaşam alanına duyulan talebin, Konya'da da yansımaları görülmüş ve piyasa koşullarında gün geçtikçe daha büyük konutların üretilmesine sebep olmuştur. Bu çalışmada, Konya kentinde farklı dönemden ve alanlardan seçilmiş 10.241 konut analiz edilmiştir. Bulgular kentte yıllar içerisinde ortalama konut büyüklüklerinin değiştiğini göstermektedir. Şöyle ki; 1950 yilından önce üretilmiş konutlar ortalama $130 \mathrm{~m}^{2}$ iken, 1950-2000 yılları arası üretilmiş konutlar ortalama $160 \mathrm{~m}^{2}$ ve 2000 yilından sonra üretilmiş konutlar ortalama $185 \mathrm{~m}^{2}$ büyüklüğe sahiptir (Öncel, 2019). 


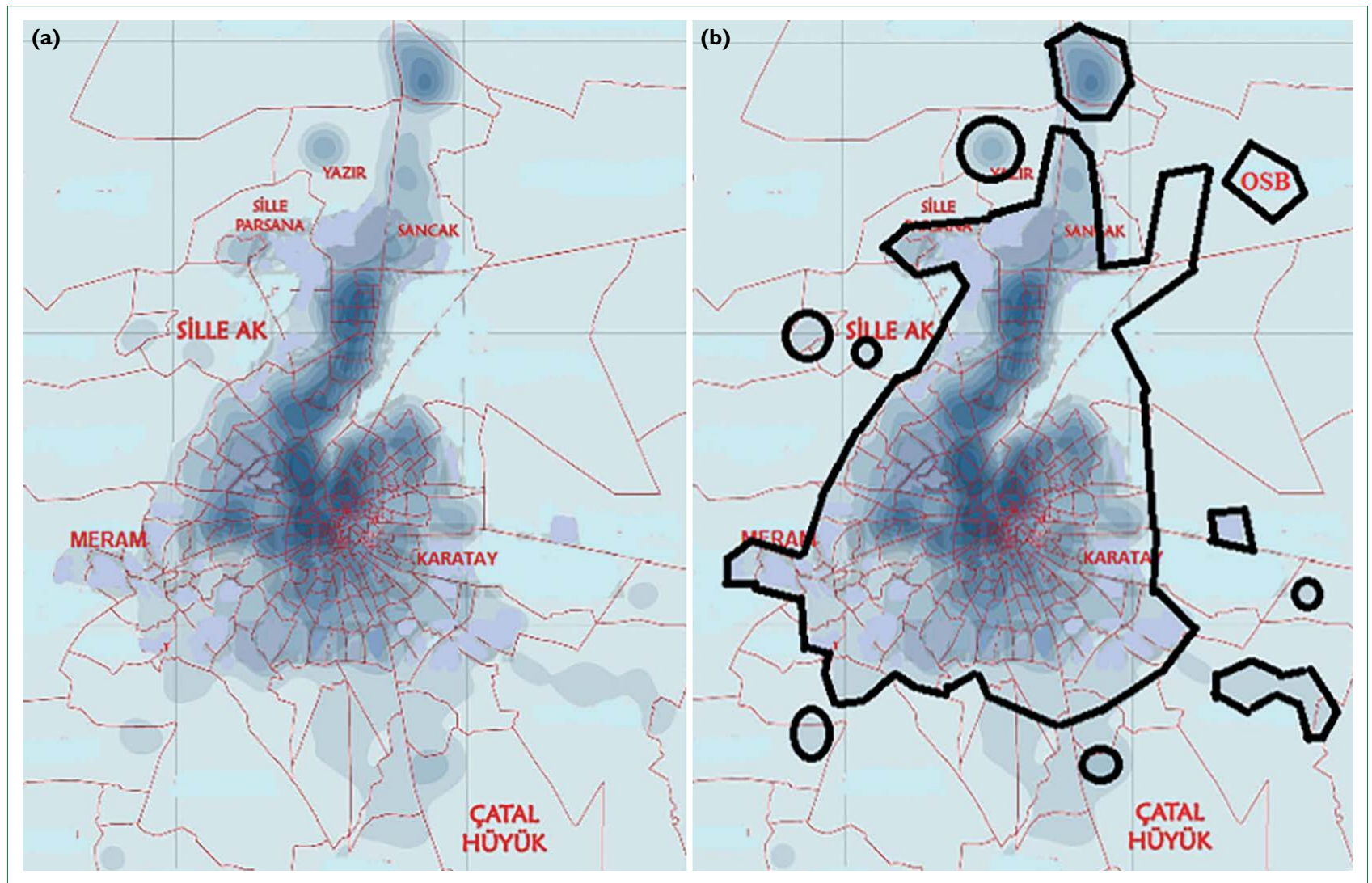

Şekil 5. (a) Konya kentsel alan nüfus yoğunlukları (b) Kent makroformu ve sıçramalı gelişme alanları [Kaynak: Konya Büyükşehir Belediyesi, Kent Bilgi Sistemi verilerinden faydalanılmıştır (2020) (Koyu renkler nüfus yoğunluğu yüksek alanları temsil etmektedir)].

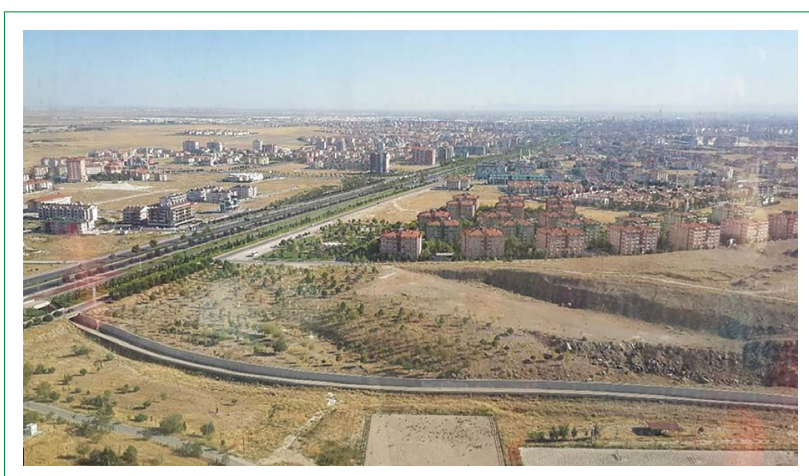

Şekil 6. Yeni gelişme alanlarının kuzeyden görünüşü (Kaynak: Kişisel arşiv, 2017).

\section{Ulaşım ve Planlama}

Tüm bu etmenlerin yanında artan otomobil sahipliliği ve kentin planlanmasında otomobil odaklı ulaşım sisteminin benimsenmesi de kentin saçaklanmasında önemli etkilere sahiptir. Son yıllarda kentte otomobille ulaşımı kolaylaştırma yönünde katlı kavşak çözümleri, geniş yollar gibi ulaşım yatırımlarının öncelendiği ancak toplu taşımayı geliştirecek açıımların yeterince geliştirilmediği söylenebilir. Örnek vermek gerekirse, kente 2004 yılına kadar 9 tane alt ve üst

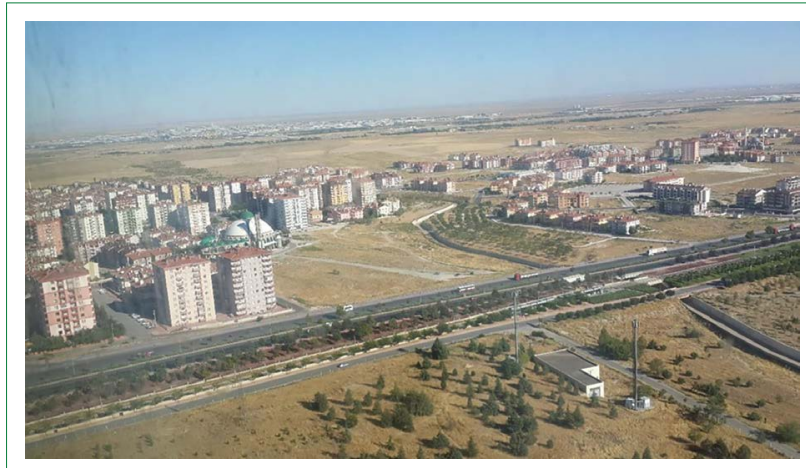

Şekil 7. Konya'nın kuzeyinde bulunan Bosna Hersek ve Sancak Mahalleleri (Kaynak: Kişisel arşiv, 20I7).

geçit bulunurken 2004-2018 yılları arasında 92 tane alt ve üst geçit inşa edilmiştir, bunun yanında tramvay hattına ise 2015 yılında 4,4 km ilave hat yapılmıştır (Konya Büyükşehir Belediyesi, 2018).

Özetle Konya kentinde saçaklanma diğer kentlere kıyasla farkI bir süreç izlemiştir. Büyük kentlerde planlamanın kontrolü dışında gelişen fiziki yapılaşmalar Konya kentinde yaşanmadığından aslında 'planlamanın kontrolünde' bir saçaklanma biçimi gerçekleşmiştir. Kentin güneyinde verimli tarım toprakla- 


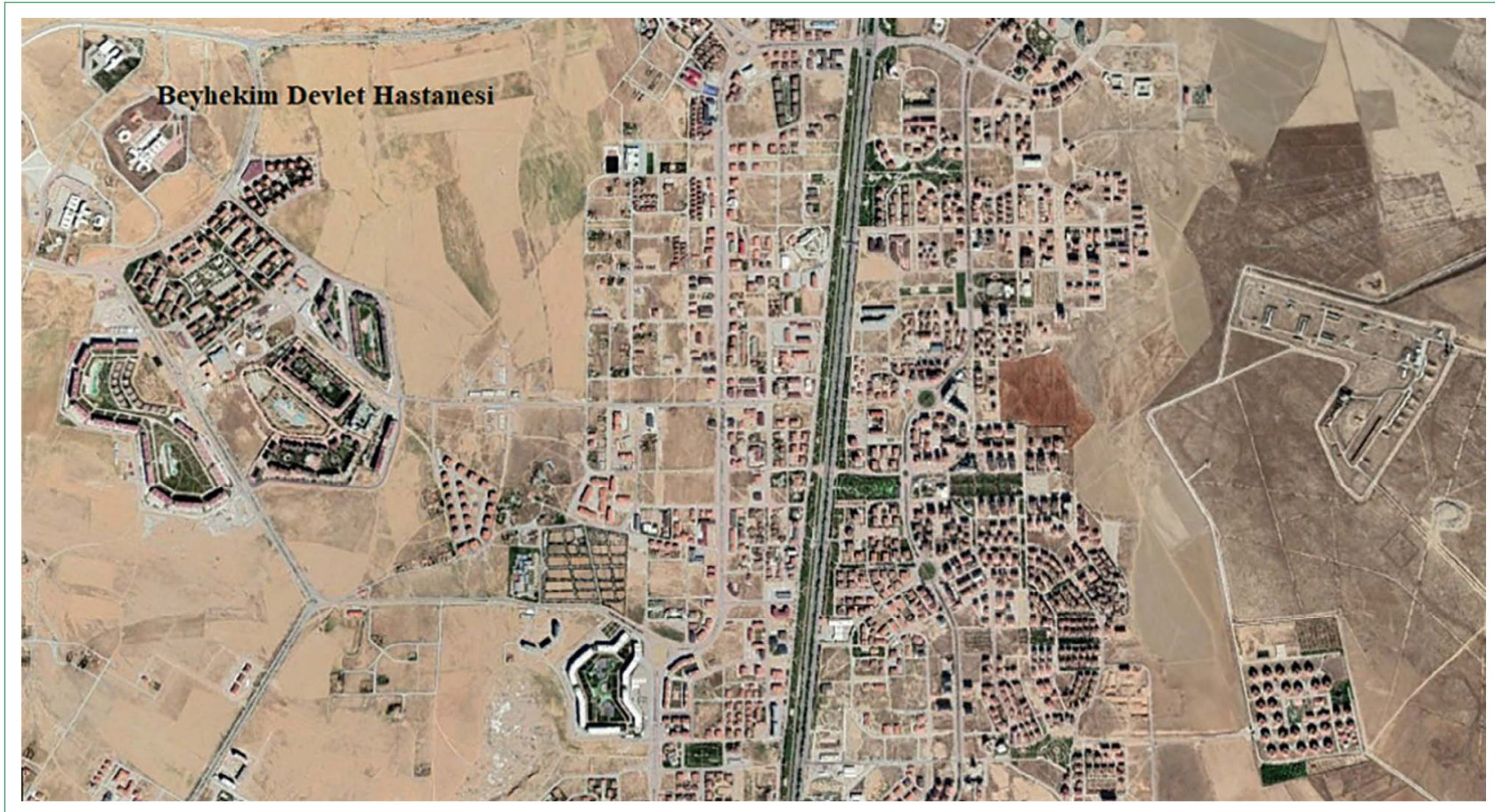

Şekil 8. Konya'nın kuzeyinde yeni gelişme alanları-uydu fotoğrafı (Kaynak: Google maps, 2018) (Erişim tarihi: 23.01.2020).

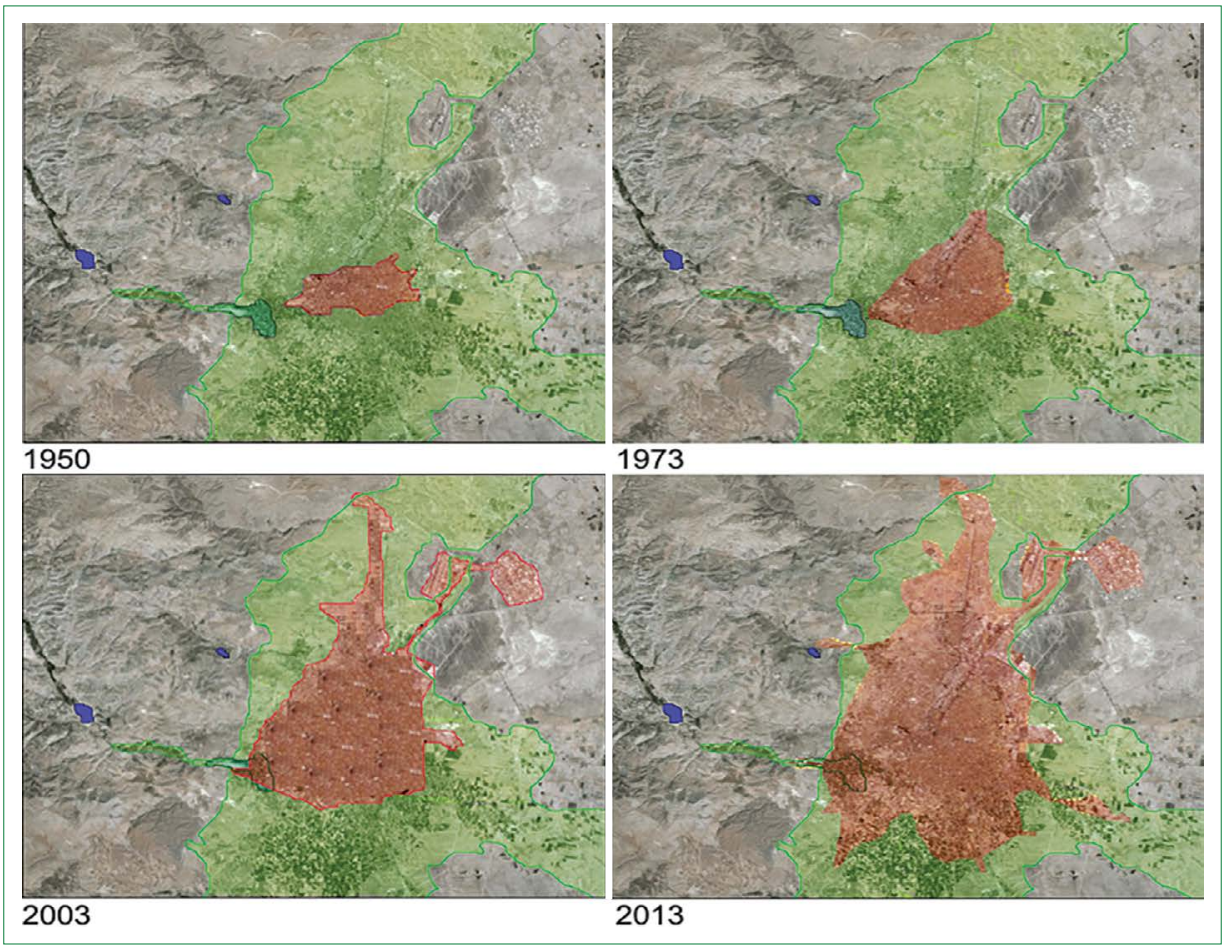

Şekil 9. Konya'da 1950-1973-2003-20I 3 yıllarında kentsel alan (Kırmızı leke kentsel alanı, yeşil alan verimli tarım topraklarını göstermektedir) [Kaynak: Büyükşehir Belediyesi Arşivi, hava fotoğrafları ve anonim (1992)].

rının, batısında topografik eşiklerin yer alması ve yerleşmeye en uygun zemin yapısının kuzeyde bulunması nedeniyle kentin gelişimi planlar aracılığıyla kuzeye yönlendirilmiştir. Dolayısıyla Konya'da kentsel büyüme yağ lekesi biçiminde her yöne değil, yoğun olarak kentin kuzeyinde gelişen bir nitelik taşımaktadır. Planlar aracılığıyla da kentsel alan -çok düşük bir yoğunlukla nüfusun ihtiyacının üzerinde alan imara açılarak- çeperlere doğru genişlemiştir (Şekil II). 


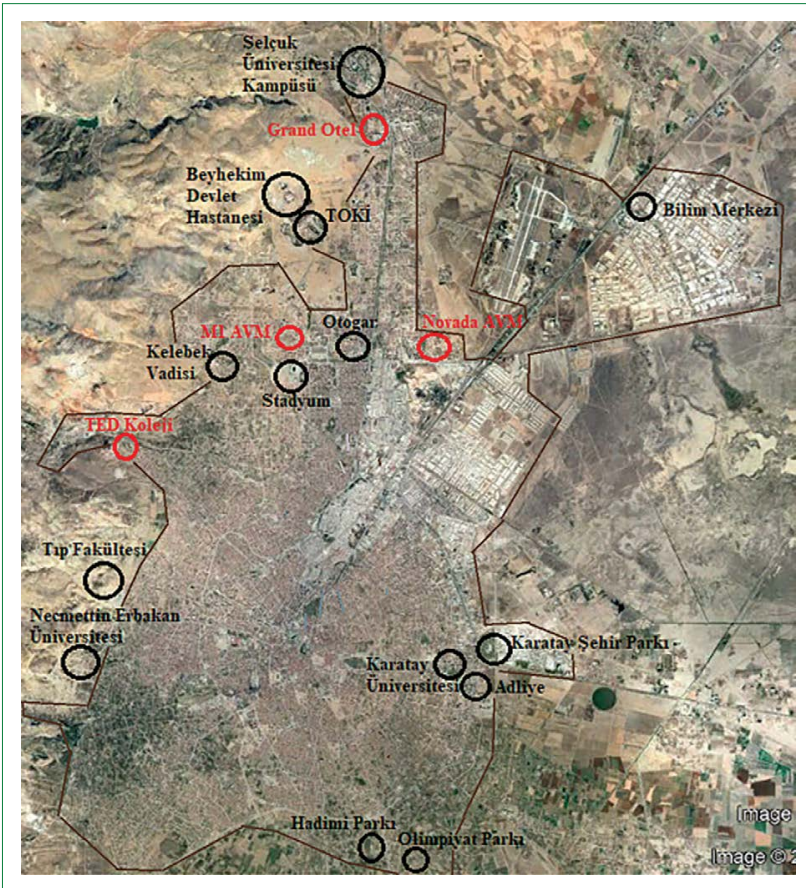

Şekil 10. Konya kentinde son yıllarda kamu ve özel sektör yatırımlarının yer seçimi (Google Earth, 2020 uydu görüntüsünden faydalanılmıştır).

\section{Sonuç ve Değerlendirme}

Yirminci yüzyılın ikinci yarısından itibaren kentsel alanlarda nüfusun artmasının yanında nüfusun ihtiyacının üzerinde alanın yapılaşmasıyla kentlerin çevrelerine doğru düşük yoğunlukla ve arada boşluklar bırakarak, büyük bir hızla büyüdüğü görülmekte, kentlerin bu yeni büyüme biçimi 'kentsel saçaklanma' olarak adlandırımaktadır. Kentsel saçaklanmanın literatürde farklı tanımları yer alsa da, son çalışmalar sebep ve sonuçlarından ayrışmış bir tanım üzerinde durmaktadır. Kısaca tanımlanırsa, kentsel nüfus yoğunluklarının düştüğü, makroformdan ayrışış sıçramalı gelişmenin görüldüğü bir kentsel büyüme biçimidir. Kentsel saçaklanmanın ortaya çıkmasında tüm dünya kentleri için geçerli olan bir takım temel etmenlerden söz etmek mümkündür. Ancak her coğrafya ve ülkenin kendi koşulları, kentsel saçaklanmayı ortaya çıkaran farklı dinamiklere sahip olmasına neden olmaktadır. Avrupa'da Sanayi Devrimiyle saçaklanmanın ilk aşamaları yaşanırken Amerika'da banliyöler saçaklanmanın dramatik biçimde ortaya çıkmasının ana sebebi sayılmaktadır. Türkiye'de ise 1950'lerden sonra kırsal alandan kentlere göç olgusu kentlerde nüfus artışına yol açmıştır. $O$ dönemde büyük kentlerde konut açığı ile birlikte gecekondulaşma ve kaçak yapılaşma daha sonraki yıllarda kentlerin yayılmasında ve saçaklanmasında ciddi etkilere sahip etmenlerdir. Daha sonra imar aflarıyla kente katılan ve parsel ölçeğinde ya da kentsel dönüşüm alanı ilan edilen bu alanlarda yoğunlukların artması söz konusu olmuştur. 1980 sonrasında ise Türkiye'nin ekonomik paradigmasının değişmesine paralel olarak oluşan sermaye piyasaları, büyük projeler için kentin çeperinde arazi

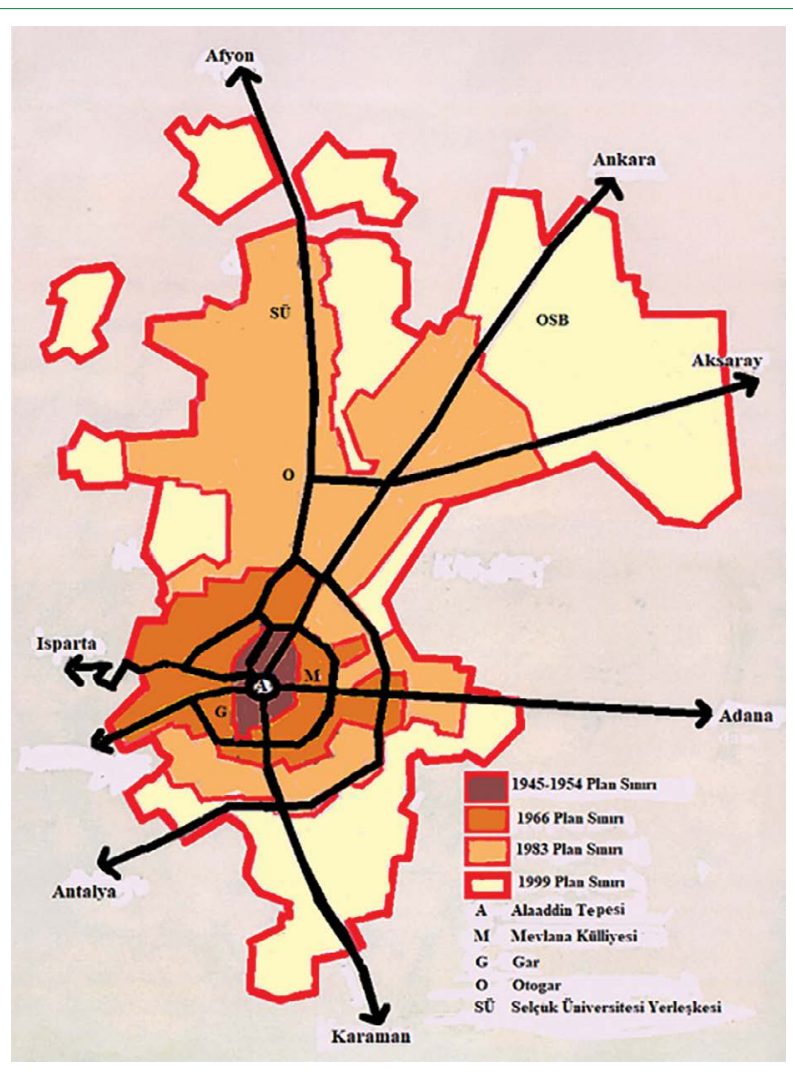

Şekil II. Konya kentinde 1954, 1966, 1983 ve 1999 planlarıla yapılaşmaya açılan alanlar (Kaynak: Baydar, 1954, Taşçı ve Berksan, 1967, Taşçı, 1983, Taşçı, 1999'dan faydalanılmışıı).

talebi ile kentleri şekillendirmeye başlamıştır. Artık kentler yağ lekesi gibi tek tek binaların eklemlenmesiyle değil büyük parçaların eklemlenmesiyle büyümeye başlamıştır. Diğer yandan 1980'lerden sonra inşaat sektörünün büyüme dönemi ve imar yetkilerinin yerel yönetimlere devredilmesi, kentlerde imar ve yapım faaliyetlerinin hız kazanmasına ve kentlerin çepere doğru saçaklanmasına neden olmuştur. Aynı dönemde kamu yatırımlarının desantralizasyonu da bu süreci hızlandırmıştır.

Konya kentinde ise kırdan kente göç hareketlerinin başladığı 1960'lardan sonra nüfus artışıla birlikte kentsel büyümenin hız kazandığı görülmektedir. Bu dönemde kentler üzerinde büyük etkiler doğuran gecekondu olgusu Konya kentinde doğru konut ve planlama politikaları neticesinde yaşanmamışır. Konya kentinde 1945 yllından itibaren onaylanan imar planları incelendiğinde 1980 'den sonra kentsel alanın nüfus ihtiyacının üzerinde arttığı hatta sıçramalı gelişmenin planlar aracılığıyla üretildiği görülmektedir. Yıllar içerisinde kentte nüfus yoğunlukları azalmış, hemen hemen tüm kamu ve özel sermaye yatırımları kent çeperinde yer seçerek kentin arada boşluklar bırakarak büyümesine neden olmuştur. Türkiye'de büyük kentlerde planlamanın kontrolü dışında gelişen fiziki yapılaşmalar Konya kentinde yaşanmadığından aslında 'planlamanın kontrolünde' bir saçaklanma biçimi söz konusu olmuştur. Bu 
çalışma Konya kentinde $1980^{\prime}$ lerden sonra yaşanan kentsel saçaklanma sürecinin nedenleri ile ilgili üretilmiş ilk çalışmadır. Bu anlamda literatüre katkı sağlamayı amaçlamaktadır. Bu çalışmadan sonra Konya kentinde kentsel saçaklanmanın ölçülmesi ve önüne geçilebilmesi için geliştirilecek politika, planlama kararları ve uygulamaların ele alınması faydalı olacaktır.

\section{KAYNAKLAR}

Abar, H., Karaaslan, A. (2013). Konut Talep Edenlerin Özellikleriyle Talep Edilen Konutun Özellikleri Arasındaki İlişkinin Çoklu Uyum Analizi Yöntemi İle İncelenmesi: Atatürk Üniversitesi Personel Örneği, Atatürk Üniversitesi İktisadi ve İdari Bilimler Dergisi, cilt:27, sayı:3.

Akkoyunlu Ertan, K., 2004. 20. Yüzyıl Kent Ütopyaları. Çağdaş Yerel Yönetimler, 13(3), 5-21.

Akseki, H. (2011). Kentsel Yayılmanın Tarım Arazileri Üzerindeki Etkisi: Konya Kenti Örneği. Yüksek Lisans Tezi, Selçuk Üniversitesi/Fen Bilimleri Enstitüsü, Konya.

Angel, S., Sheppard, S.C., Civco, D. (2005). The Dynamics of Global Urban Expansion, Transport and Urban Development Department The World Bank, Washingdon D.C.

Anonim (1992). Konya İli Arazi Varlığı, Tarım ve Köy İşleri Bakanlığı Köy Hizmetleri Genel Müdürlüğ̈̈, Ankara.

Arbury, J. (2005). From Urban Sprawl To Compact City: an analysis of urban growth management in Auckland, Citeseer, University of Auckland.

Atakan, G. (2018). 2000'ler Türkiye'sinde 'Mekan-Mesken' Kavramlarının 'Değer' Kavramı Üzerinden Sorgulanması: Kuramsal Bir İnceleme, Grid, vol 1, no 1 , s.52.

Balaban, O. (2011). İnşaat Sektörü Neyin Lokomotif, Birikim Dergisi, 270, s.19-26.

Barnes, K. B., Morgan III, J. M., Roberge, M. C. ve Lowe, S. (2001). Sprawl Development: Its Patterns, Consequences, And Measurement, Towson University, Towson, 1-24.

Baydar, F., Baydar, L. (1954). Konya İmar Planı İzah Raporu, Ankara.

Berry, B. (2008). Urbanization (Urban Ecology An International Perspective on the Interaction Between Humans and Nature), Online ISBN, 978970 .

Brueckner, J. K. (2000). Urban Sprawl: Diagnosis And Remedies, International Regional Science Review, 23 (2), 160-171.

Bruegmann, R. (2006). Sprawl: A Compact History, University of Chicago press, p.28-64.

Buğra, A. (2000). Devlet Piyasa Karşıtlığının Ötesinde İhtiyaçlar Ve Tüketim Üzerine Yazılar, İstanbul: İletişim Yayınları.

Cobbinah, P.B., Amoako, C.(2012), Urban Sprawl and the Loss of Peri-Urban Land in Kumasi, Ghana, International Journal of Social and Human Sciences (6), 388-397.

Couch, C., Leontidou, L., Arnstberg, K. (2009). Urban sprawl in Europe: landscapes, land-use change $\&$ policy / edited by Chris Couch, Lila Leontidou, and Gerhard Petschel-Held. 2009. Wiley\& Blackwell Pub.

Chin, N. (2002). Unearthing The Roots Of Urban Sprawl: a critical analysis of form, Function and Methodology, 1467-1298.

Ewing, R., Pendall, R. ve Chen, D. (2002). Measuring Sprawl And İts İmpact: The character and consequences of metropolitan expansion, Washington, DC: Smart Growth America.

Fishmann, R. (2002). 20. Yy'da Kent Ütopyalar1- Ebenezer Howard, Frank Lloyd Wright, Le Corbusier. Duru B.,Alkan A. (Ed), 20. Yüzyıl Kenti, İmge yayınları, s. 107-126.

Frumkin, H., Frank, L. ve Jackson, R. J. (2004). Urban Sprawl And Public Health: Designing, planning, and building for healthy communities, Island Press, p.1-34.

Galster, G. ve diğ. (2001). Wrestling Sprawl to the Ground: Defining and Measuring an Elusive Concept, Housing Policy Debate, Vol: 12/4, 681718.

Gillham, O. (2002). The Limitless City: a primer on the urban sprawl debate, Island Press, p.3-45.

Howard, E. (1902). Garden Cities of Tomorrow, Sonnenschein\&co. Y, London. 
Kaba, E. (2008). Konut Alma Kararlarını Etkileyen Faktörler ve Alıcı Profilini Belirlemeye Yönelik Bir Araştırma, Yayınlanmamıș Yüksek Lisans Tezi, Marmara Üniversitesi/Sosyal Bilimler Enstitüsü.

Kangalak, İ., Işık, Ş. (2007). Kentleşmenin Yeni Ekonomik Boyutları, Ege Coğrafya Dergisi, 16 (2007), 17-35.

Karataş, N. (2007). İzmir'deki Şehirsel Saçaklanma Eğilimlerinin TorbalıAyrancılar'da Arazi Sahipliliği El Değişim Süreçlerine Etkileri, TMMOB Şehir Planciları Odası Planlama Dergisi, 2, 3-10.

Kaygalak, İ., (2006). İzmir'de Karşıyaka-Çiğli Aksının Kentsel Gelişim Süreci Ve Bu Gelişimi Etkileyen Faktörler, Yüksek lisans tezi, Ege Üniversitesi, SBE.

Keleş, R. (1996). Kentleşme Politikası, Ankara: İmge, s: 224-228.

Konya Büyükşehir Belediyesi, 2018,'Başkan Akyürek Konya ve Ülke Gündemini Değerlendirdi' https://konya.bel.tr/haberbasin.php?haberID=6226 \&hDurum $=$ METIN

Kömürcüoğlu, A., Konya İmar Planı İzah Raporu, 1946.

Le Corbusier, C.E.J. (1987). A contemporary city, from the city of tomorrow and its planning. New York: Dover.

Ludlow, D. (2006). Urban Sprawl İn Europe: The ignored challenge.

McIntyre, N. E., Knowles-Yánez, K. ve Hope, D. (2008). Urban Ecology As An Interdisciplinary Field: differences in the use of "urban" between the social and natural sciences, In: Urban ecology, Eds: Springer, p. 49-65.

Milanovic, N.P., Korycka, M.G., Rink D. (2009). Sprawl in the Post-Socialist City: The Changing Economic and Institutional Context and European Cities, Ed: Couch, C., Leontidou, L., Arnstberg, K. Urban sprawl in Europe: landscapes, land-use change $\&$ policy / edited by Chris Couch, Lila Leontidou, and Gerhard Petschel-Held. 2009. Wiley\& Blackwell Pub.

Nechyba, T. and Walsh, R.P. (2004). Urban Sprawl. Journal of Economic Perspectives-Volume 18 (4): 177-200.

OECD (2018). Rethinking Urban Sprawl: Moving Towards Sustainable Cities, OECD Publishing, Paris.

Oueslati, W., Alvanides, S., Garrod, G. (2015). Determinants of Urban Sprawl in European Cities, Urban Studies, vol. 52(9), 1594-1614.

Öncel, H. (2019). Mekanın Tasarımı ve Kullanımına Bağlı Olarak Kentsel Yayılmayı Etkileyen Unsurlar: Konya Kenti Örneği, Doktora Tezi, Selçuk Üniversitesi/Fen Bilimleri Ens., Konya.

Pendall, R., (1999). Do land-use controls cause sprawl?, Environment and Planning B: Planning and Design, 26 (4), 555-571.

Powell, R., 2007, Urban Sprawl in Reno-Sparks, Washoe County, Nevada, University of Nevada, Reno.

Sılaydın Aydın, M.B., Kahraman, E.D. (2019). Kompakt Kent Ölçütlerinden Biri Olan Yoğunluk Tespiti ve Değerlendirmesi: Türkiye Kentleri (İ Merkezleri) Örneği, Planlama Dergisi 29(2): 171-193.

Soule, D. C. (2006). Defining And Managing Sprawl, Urban Sprawl: a comprehensive reference guide, 3-11.

Squires, G. D. (2002). Urban Sprawl And The Uneven Development Of Metropolitan America, Urban sprawl: Causes, consequences, and policy responses, 1-22.

Taşçı, Y. (1983). Konya 2000 Çevre Düzeni Planı Açıklama Raporu, Taş̧ı Mimarlik/Planlama Atölyesi, Ankara.

Taşçı, Y., 1999, Konya 2020 Nazım planı revizyon açıklama raporu, Taşçı Mimarlik/Planlama Atölyesi, Ankara.

Taşçı, Y., Berksan, H. (1967). Konya İmar Müsabakası İzah Notu, Ankara.

Tekeli, İ. (2013). Türkiyénin Kentleşme Deneyiminden Öğrenebileceklerimiz. TEPAV y. 5-21.

Tercan, B. (2018). 1948'den Bugüne İmar Afları, Mimarlık Dergisi, sayı 403, s: $20-26$.

Wei, Y.D., Ewing, R. (2018). Urban Expansion, Sprawl and Inequality, Landscape and Urban Planning, 177 (2018), 259-265.
Weitz, J. ve Moore, T., 1998, Development inside urban growth boundaries: Oregon's empirical evidence of contiguous urban form, Journal of the American Planning Association, 64 (4), 424-440.

Wright, F.L. (1932). The Disappearing City, University of Michigan, New York.

Yaşar, C. G. (2010). Politics of Urban Sprawl: The Case of Ankara, METU, The Graduate School of Social Science.

Yenice, S. (2005). Kentsel Planlama Sürecinde Konya Kent Formunun Gelişimi Üzerine Bir

Araştırma, Yüksek Lisans Tezi, Selçuk Üniversitesi/ Fen Bilimleri Enstitüsü, Konya.

Yenice, S. (2012). Konya Kentinin Planlama Tarihi ve Mekansal Gelişimi, Erciyes Üniversitesi Fen Bilimleri Enstitü Dergisi, 28(4): 343-350.

Yüksel, Ü. D. (2012). Antikçağdan Günümüze Kent Ütopyaları, Kent Ütopyaları, İdeal kent, sayı:5. 